\title{
Late Cretaceous to ?Paleocene freshwater, brackish-water and marine molluscs from Al-Khodh, Oman
}

\author{
Simon Schneider, Heinz A. Kollmann \& Martin Pickford
}

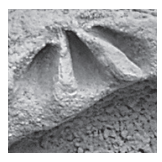

\begin{abstract}
Bivalvia and Gastropoda from the late Campanian to Maastrichtian deltaic Al-Khodh Formation and from the overlying ?Paleocene shallow marine Jafnayn Limestone Formation of northeastern Oman are described. Freshwater bivalves include three species of Unionidae, left in open nomenclature, due to limited preservation. These are the first pre-Pleistocene unionids recorded from the Arabian Peninsula, where large freshwater bivalves are absent today. Brackish-water bivalves are represented by two species of Cyrenidae. Geloina amithoscutana sp. nov. extends the range of Geloina to the Mesozoic and to ancient Africa. Muscatella biszczukae gen. et sp. nov. has a unique combination of characters not shared with other genera in the Cyrenidae. Brackish-water gastropods comprise Stephaniphera coronata gen. et sp. nov. in the Hemisinidae; Subtemenia morgani in the new genus Subtemenia (Pseudomelaniidae); Cosinia sp. (Thiaridae); Pyrazus sp. (Batillariidae); and Ringiculidae sp. indet. From the Jafnayn Limestone Formation, several marginal marine mollusc taxa are also reported. The fossils are assigned to four mollusc communities and associations, which are indicative of different salinity regimes. - Key words: Unionidae, Cyrenidae, Pseudomelaniidae, Hemisinidae, taxonomy, palaeobiogeography.
\end{abstract}

Schneider, S., Kollmann, H.A. \& Pickford, M. 2020. Late Cretaceous to ?Paleocene freshwater, brackish-water and marine molluscs from Al-Khodh, Oman. Bulletin of Geosciences 95(2), 179-204 (10 figures, 5 tables). Czech Geological Survey, Prague. ISSN 1214-1119. Manuscript received August 12, 2019; accepted in revised form March 30, 2020; published online May 30, 2020; issued May 30, 2020.

Simon Schneider, CASP, West Building, Madingley Rise, Madingley Road, Cambridge CB3 0UD, UK; simon. schneider@casp.org.uk•HeinzA. Kollmann, Natural History Museum Vienna, Department of Geology \& Palaeontology, Burgring 7, 1010 Wien, Austria - Martin Pickford, Sorbonne Université (CR2P, MNHN, CNRS, UPMC-Paris VI), 8, rue Buffon, 75005, Paris, France

Globally, the evolution and phylogeny of freshwater and brackish-water molluscs is currently a topic of great interest, mostly due to the importance of these taxa for conservation biology (e.g. Lopes-Lima et al. 2016, 2018; Do et al. 2018; Zieritz et al. 2018). Most freshwater mollusc clades show a high degree of diversification, endemism and environmental restrictedness, and, as a result, species have a high risk of extinction (e.g. Cuttelod et al. 2011). Brackish-water taxa, although often more widespread, show similar patterns and face similar problems, as suitable habitats are often confined to river deltas, which are restricted in extent and usually densely populated by humans (e.g. Barnes 1999, Szabo et al. 2016). Consequently, combined molecular and morphologic studies of freshwater and brackish-water molluscs are en vogue, and for several groups, comprehensive phylogenies at global scale are gradually becoming available.

In contrast, the fossil component of freshwater and brackish-water mollusc evolution is significantly understudied and comparatively poorly understood. There are several reasons for this. Most importantly, the fossil record of these taxa is scattered and discontinuous, since the preservation potential of the strata enclosing them is low (e.g. Dunhill et al. 2014). As a result, many species or genera are only known from their type locality (e.g. Henderson 1935, p. 4) and phylogenetic relationships remain enigmatic. Additionally, the level of convergence in many of the higher taxa of freshwater and brackishwater molluscs is an issue, as new and surprising cases are continuously revealed by molecular studies (e.g. Bolotov et al. 2017, 2018). Last, but not least, many freshwater and brackish-water species are highly variable and shells react plastically to changes in habitat or water chemistry.

Whoever is not put off by these caveats and attempts to apply rigorous taxonomy and systematics to fossil freshwater and brackish-water shells is, however, often rewarded with interesting results concerning evolutionary relationships and pathways, palaeobiogeography or palaeoecology. Moreover, fossils supply the component of time to molecular phylogenetics and are thus essential for the calibration of evolution. Such a case, exemplified by a restricted, low diversity fauna from the latest Cretaceous of northern Oman, is presented herein. 


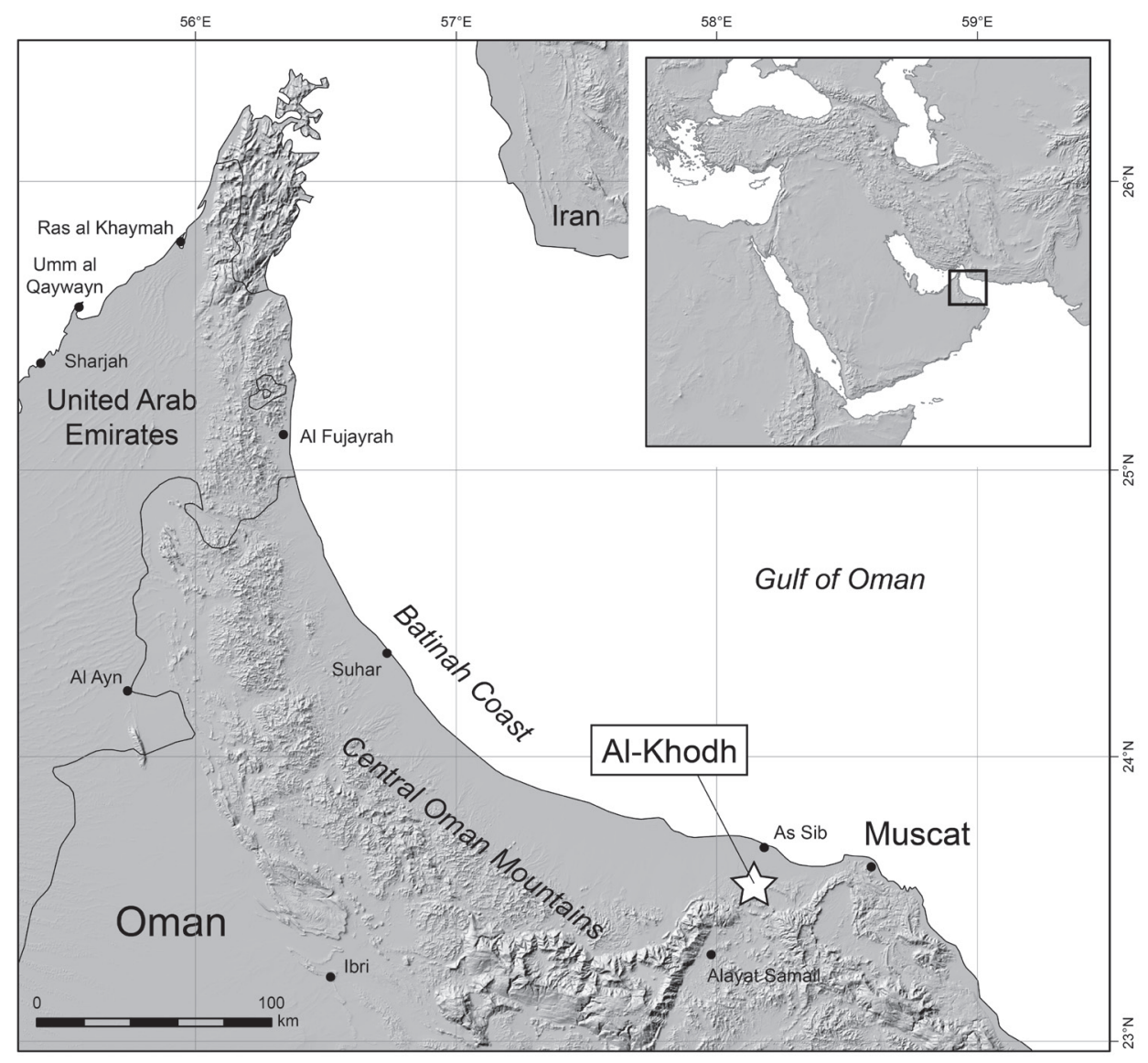

Figure 1. Map of the northern coast of Oman. The area of AlKhodh is indicated by a star.

The study area around Al-Khodh is near Muscat, the capital of Oman. The outcrops are located approximately $10 \mathrm{~km}$ west of Muscat Airport, close to the Batinah Coast in the foreland of the Central Oman Mountains (Fig. 1). The Al-Khodh Formation, which yielded most of the studied fossil assemblages, was defined by Nolan et al. (1990; originally spelled 'Al-Khawd Conglomerate Formation'). It comprises a succession of polymict conglomerates, lithic sandstones, shale and subordinate microcrystalline carbonates, and has been interpreted as a fan delta complex by Nolan et al. (1990). The AlKhodh Formation is up to $860 \mathrm{~m}$ thick and bounded by unconformities. It was deposited on top of the Semail Ophiolite and is overlain by the marine Jafnayn Limestone Formation. No comprehensive dating is available for the Al-Khodh Formation. However, the Semail Ophiolite was obducted onto the Oman margin during the middle to late Campanian, and the basal Jafnayn Limestone Formation is supposed to be late Palaeocene in age (Nolan et al. 1990, and references therein). Given that ornithischian dinosaur remains have been found in the Al-Khodh Formation, a pre-Cenozoic, potential late Campanian to Maastrichtian age was deduced by Nolan et al. (1990). The Jafnayn Limestone Formation is dominantly composed of nodular limestones, with minor marly intervals. It is concordantly, but presumably paraconformably overlain by the shaleand marl-dominated Rusayl Formation (Nolan et al. 1990). The stratigraphy of both formations is based on echinoids, which define a late Palaeocene to basal Eocene age range for the Jafnayn Limestone Formation (Nolan et al. 1990).

From the coarser-grained beds of the Al-Khodh Formation, articulated 'corbiculid bivalves' and gastropods were mentioned by Nolan et al. (1990). Pickford (2017) remarked that freshwater molluscs are confined to the lower half of the succession, and become gradually replaced by brackish-water and finally fully marine fauna up-section. Two species of the freshwater gastropod genus Lanistes were described in open nomenclature by Pickford (2017). The remaining mollusc taxa, with exclusion of the Ostreoidea, are studied herein for the first time.

\section{Material and methods}

The fossils described herein were collected in February 2015 at the following localities at Al-Khodh, Oman (Tab. 1; GPS WGS 84 grid).

Specimens were cleaned with water, brush and needles. All specimens were coated with ammonium chloride for photographs. 
All fossils are curated at the Oman Natural History Museum, Muscat (ONHM), under collection numbers ONHM-F-4411 to 4433.

\section{Systematic palaeontology}

The systematic arrangement of the Bivalvia is adopted from MolluscaBase (2018). The systematic arrangement of the Gastropoda follows Bouchet et al. (2017). Where permitted by preservation, measurements were taken with callipers to the nearest half millimetre. Measurements have only been taken from complete or near-complete specimens in bivalves. Thickness measurements for single valves have been doubled. Abbreviations: AA - apical angle; $\mathrm{H}$ - height; $\mathrm{HB}$ - height of last whorl; L - length; $\mathrm{T}$ - thickness; $\mathrm{W}$ - width.

Class Bivalvia Linnaeus, 1758

Subclass Palaeoheterodonta Newell, 1965

Order Unionida Stoliczka, 1871

Superfamily Unionoidea Rafinesque, 1820

Family Unionidae Rafinesque, 1820

Remarks. - The three species of Unionidae described below come from a single fossil assemblage. The original, nacreous aragonite of the shells is recrystallized as sparry calcite. All shells are disarticulated and their surfaces and hinges are more or less strongly worn. No hinge teeth are preserved, preventing assignment at genus or species level. Typical unionid shell features include the generally elongate oval to slightly kidney-shaped outlines of the shells; long, slender nymphs (Fig. 2B2, C2); deeply engraved anterior adductor muscle scar and distinct pedal retractor muscle scar (Fig. 2D); and fine radial striation of inner shell layers (Fig. 2A, C1, E).

\section{Unionidae sp. indet. 1}

Figure 2A, C, E

Material. - 17 left valves and 4 right valves, all fragmentary, from the Al-Khodh Formation at locality MP3 (ONHM-F-4428).

Description. - Shell elongate-oval in outline, weakly inflated. Umbo blunt, barely protruding; positioned almost centrally, only slightly shifted towards the anterior end; faintly prosogyrate. Outer shell layer only preserved in patches; smooth where seen. Second shell layer with commarginal growth lines and slightly undulating radial striation, as often seen in corroded (fossil) unionoids. Hinge plate prominent; hinge teeth eroded. Nymph elongate, relatively long, submerged below dorsal shell margin.

Table 1. Localities and communities/associations. For each locality the locality name; GPS coordinates; and the taxa recorded are given. Colours indicate the four mollusc communities/associations: green = unionid community; yellow = Geloina association; blue = Muscatella association; red $=$ marine community.

\begin{tabular}{|c|c|c|c|c|c|c|c|c|c|c|c|c|c|c|c|c|c|}
\hline Locality & Latitude & Longitude & 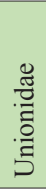 & 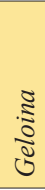 & 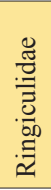 & 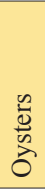 & 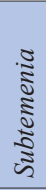 & 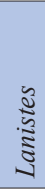 & 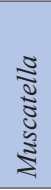 & 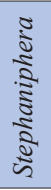 & 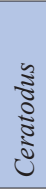 & 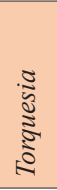 & $\begin{array}{l}\tilde{\Xi} \\
0 \\
0\end{array}$ & ह & 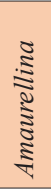 & 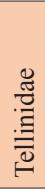 & 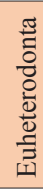 \\
\hline AK33 & $23^{\circ} 32^{\prime} 45.6^{\prime \prime} \mathrm{N}$ & $58^{\circ} 09^{\prime} 19.4^{\prime \prime} \mathrm{E}$ & & & & & $\mathrm{x}$ & & & & & & & & & & \\
\hline AK51 & $23^{\circ} 33^{\prime} 05.5^{\prime \prime} \mathrm{N}$ & $58^{\circ} 08^{\prime} 42.6^{\prime \prime} \mathrm{E}$ & & & & $\mathrm{x}$ & $\mathrm{x}$ & $\mathrm{x}$ & $\mathrm{x}$ & $\mathrm{x}$ & & & & & & & \\
\hline MP1 & $23^{\circ} 32^{\prime} 53.4^{\prime \prime} \mathrm{N}$ & $58^{\circ} 08^{\prime} 37.8^{\prime \prime} \mathrm{E}$ & & $\mathrm{x}$ & & & & & & & & & & & & & \\
\hline MP2 & $23^{\circ} 32^{\prime} 55.4^{\prime \prime} \mathrm{N}$ & $58^{\circ} 08^{\prime} 36.3^{\prime \prime} \mathrm{E}$ & & $\mathrm{x}$ & & & $\mathrm{x}$ & & & & & & & & & & \\
\hline MP3 & $23^{\circ} 33^{\prime} 02.4^{\prime \prime} \mathrm{N}$ & $58^{\circ} 08^{\prime} 36.6^{\prime \prime} \mathrm{E}$ & $\mathrm{x}$ & & & & & & & & & & & & & & \\
\hline MP4 & $23^{\circ} 33^{\prime} 05.3^{\prime \prime} \mathrm{N}$ & $58^{\circ} 08^{\prime} 16.9^{\prime \prime} \mathrm{E}$ & & $\mathrm{x}$ & & & & & & & & & & & & & \\
\hline MP5 & $23^{\circ} 32^{\prime} 50.9^{\prime \prime} \mathrm{N}$ & $58^{\circ} 08^{\prime} 39.7^{\prime \prime} \mathrm{E}$ & & $\mathrm{x}$ & & & $\mathrm{x}$ & $\mathrm{x}$ & & & & & & & & & \\
\hline MP6 & $23^{\circ} 32^{\prime} 51.0^{\prime \prime} \mathrm{N}$ & $58^{\circ} 08^{\prime} 39.1^{\prime \prime} \mathrm{E}$ & & $\mathrm{x}$ & & & & & & & & & & & & & \\
\hline MP7 & $23^{\circ} 32^{\prime} 52.6^{\prime \prime} \mathrm{N}$ & $58^{\circ} 08^{\prime} 38.4^{\prime \prime} \mathrm{E}$ & & $\mathrm{x}$ & $\mathrm{x}$ & $\mathrm{x}$ & $\mathrm{x}$ & & & & & & & & & & \\
\hline MP8 & $23^{\circ} 33^{\prime} 04.7^{\prime \prime} \mathrm{N}$ & $50^{\circ} 08^{\prime} 36.1^{\prime \prime} \mathrm{E}$ & & & & & & & $\mathrm{x}$ & & & & & & & & \\
\hline MP9 & $23^{\circ} 32^{\prime} 57.6^{\prime \prime} \mathrm{N}$ & $58^{\circ} 08^{\prime} 33.9^{\prime \prime} \mathrm{E}$ & & $\mathrm{x}$ & & & & & & & & & & & & & \\
\hline MP10 & $23^{\circ} 32^{\prime} 59.6^{\prime \prime} \mathrm{N}$ & $58^{\circ} 08^{\prime} 31.9^{\prime \prime} \mathrm{E}$ & & $\mathrm{x}$ & & $\mathrm{x}$ & & & & & & & & & & & \\
\hline MP13 & $23^{\circ} 33^{\prime} 09.6^{\prime \prime} \mathrm{N}$ & $58^{\circ} 08^{\prime} 31.2^{\prime \prime} \mathrm{E}$ & & & & & $\mathrm{x}$ & & $\mathrm{x}$ & & $\mathrm{x}$ & & & & & & \\
\hline MP14 & $23^{\circ} 33^{\prime} 07.8^{\prime \prime} \mathrm{N}$ & $58^{\circ} 08^{\prime} 36.1^{\prime \prime} \mathrm{E}$ & & & & & & & $\mathrm{x}$ & $\mathrm{x}$ & & & & & & & \\
\hline Fanja Back & $23^{\circ} 26^{\prime} 26.7^{\prime \prime} \mathrm{N}$ & $58^{\circ} 10^{\prime} 39.8^{\prime \prime} \mathrm{E}$ & & & & & & & & & & $\mathrm{x}$ & $\mathrm{x}$ & $\mathrm{x}$ & $\mathrm{x}$ & $\mathrm{x}$ & $\mathrm{x}$ \\
\hline
\end{tabular}


Remarks. - The shells of this species, although incompletely characterised, are quite distinct from those of Unionidae sp. indet. 2 and 3 with regard to general shell shape. The present species has oval shells with barely protruding umbos. Species 2 is trigonally ovate with markedly protruding umbos. Species 3 has a slight but distinct incurvature of the ventral shell margin, and thus is faintly kidney-shaped in outline.

\section{Unionidae sp. indet. 2}

Figure 2B

Material. - A single, almost complete right valve, from the Al-Khodh Formation at locality MP3 (ONHM-F-4429a).

Description. - Shell high trigonally ovate in outline. Umbo blunt, distinctly protruding, faintly prosogyrate; positioned at approximately $25 \%$ of shell length. Shell outside smooth, with regular commarginal growth lines only. Nymph elongate, long (more than one third of shell length), submerged below dorsal shell margin. Shell interior unknown.

Remarks. - For differences between the three unionid species, see remarks for Unionidae sp. indet. 1 above.

\section{Unionidae sp. indet. 3}

Figure 2D, F

Material. - A single left valve and a single right valve, both fragmentary, from the Al-Khodh Formation at locality MP3 (ONHM-F-4430a, b).

Description. - Shell oval kidney-shaped in outline. Umbo blunt, barely protruding, faintly prosogyrate; positioned at approximately $30 \%$ of shell length. Ventral shell margin distinctly incurved shortly before mid-length. Outer shell layer incompletely preserved; smooth with commarginal growth lines where seen. Shell rather thick. Hinge plate prominent and wide; hinge teeth eroded. Anterior adductor muscle scar deep and internally structured. Pedal retractor muscle scar distinct; positioned directly below anterior adductor muscle scar.

Remarks. - For differences between the three unionid species, see remarks for Unionidae sp. indet. 1 above. Kidney-shaped shells are common in species belonging to the family Margaritiferidae, which is sister clade to the Unionidae. However, the shape of the hinge plate in Unionidae sp. indet. 3 suggests that there is insufficient space directly above the anterior adductor muscle scar for the strong pseudocardinal cusps commonly seen in Margaritiferidae. More importantly, the pedal retractor muscle scar is clearly positioned below the anterior adductor muscle scar, not directly behind the latter, as in Margaritiferidae. We thus consider a placement in the morphologically much more diversified Unionidae more likely.

Subclass Heterodonta Neumayr, 1884

Infraclass Euheterodonta Giribet \& Distel, 2003

\section{Euheterodonta indet.}

Material. - Two internal moulds of articulated specimens, from the Jafnayn Limestone Formation at locality Fanja Back (ONHM-F-4432a, b).

Remarks. - The larger specimen is ovate in outline, distinctly inflated, with relatively pointed, sub-terminal, distinctly prosogyrate umbos, and faint commarginal growth lines. The smaller specimen seems to be similar in shape, but is encrusted with diagenetic calcite. These characters are not indicative at genus or even family level, and could occur both in Imparidentia and Anomalodesmata. We refrain from figuring these poorly preserved specimens.

Superorder Imparidentia Bieler, Mikkelsen \& Giribet in Bieler et al., 2014

Order Cardiida Férussac, 1822

Superfamily Tellinoidea Blainville, 1814

Family Tellinidae Blainville, 1814

\section{?Tellinidae indet.}

Material. - A single fragmentary internal mould of an articulated specimen, from the Jafnayn Limestone Formation at locality Fanja Back (ONHM-F-4431a).

Remarks. - The specimen is poorly inflated, slightly inequilateral and ovate-triangular in shape, with rather pointed, slightly projecting umbos and faint commarginal growth lines. This combination of traits is most common in the Tellinidae, but could occur in a number of other euheterodont bivalve families, which renders the family assignment tentative. We refrain from figuring this fragment.

Order Venerida Gray, 1854

Superfamily Cyrenoidea Gray, 1840

Family Cyrenidae Gray, 1840

Remarks. - The classification of fossil Cyrenidae is far from settled. Some 30 genus-level names are available in this family, but several of them are only vaguely defined (e.g. Keen \& Casey 1969, Fang et al. 2009). Most of these taxa are restricted to the Cenozoic, but several genera extend back into the Mesozoic, or are entirely Mesozoic, in their distribution. Taxa with and without serrated hinge teeth occur throughout, and the phylogenetic significance 


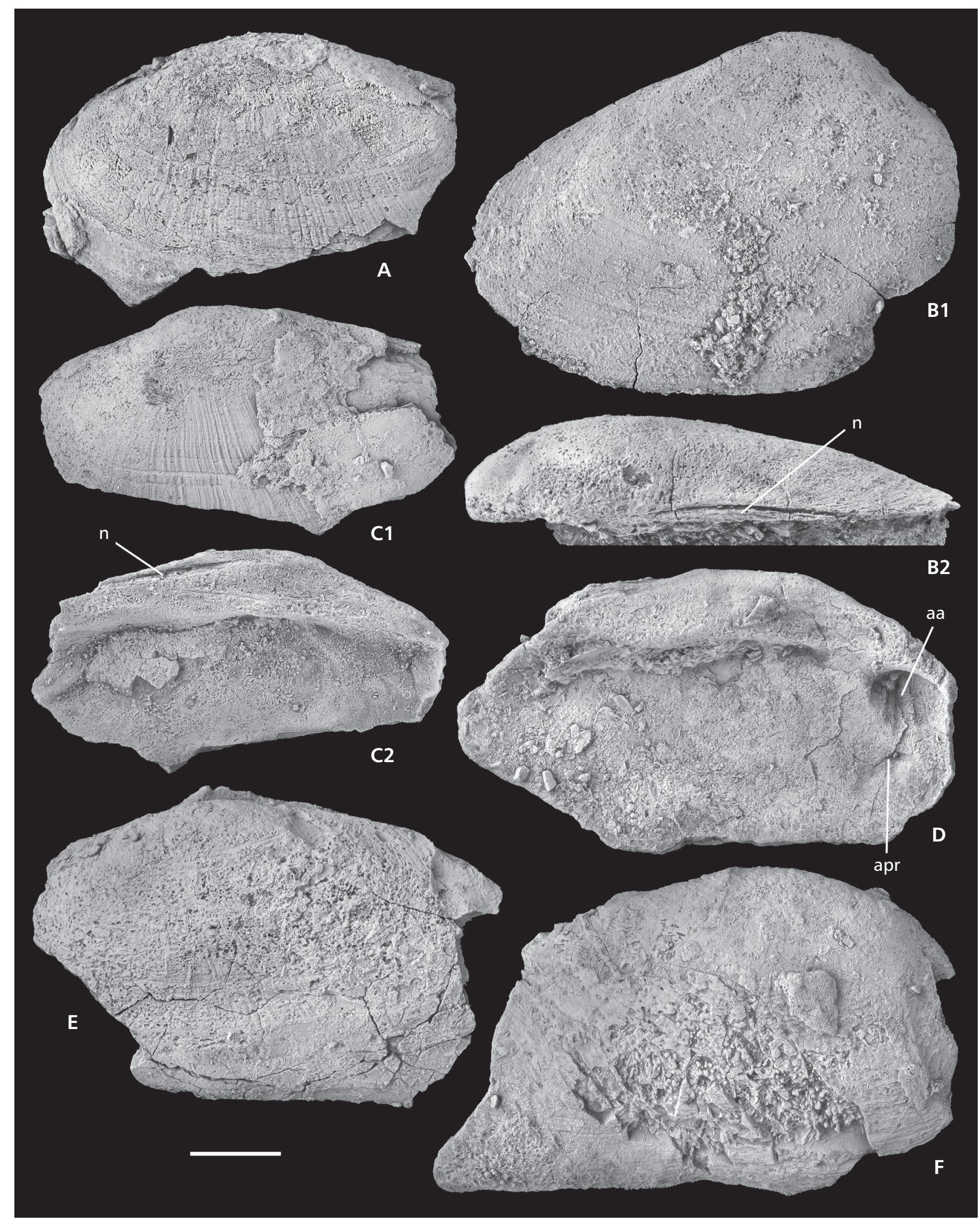

Figure 2. Unionidae from the Al-Khodh Formation at locality MP 3. • A, C, E - Unionidae sp. indet. 1; A - right valve, ONHM-F-4428a; C - left valve, ONHM-F-4428b; E - left valve, ONHM-F-4428c. • B - Unionidae sp. indet. 2, ONHM-F-4429a. • D, F - Unionidae sp. indet. 3; D - left valve, ONHM-F-4430a; F - right valve, ONHM-F-4430b. Abbreviations: aa - anterior adductor muscle scar; apr - anterior pedal retractor muscle scar; $\mathrm{n}-$ nymph. Scale bar $=10 \mathrm{~mm}$. 
of this character is unclear. Likewise, the phylogenetic significance of the presence or absence of a pallial sinus has not been clarified. In order to avoid making unsupported phylogenetic inferences, both characters are herein treated as significant for generic assignment, which leads to the establishment of a new genus below. Most cyrenid taxa are of broadly veneroid shape, i.e. short ovate, or rounded triangular. Some genera, however, have elongate ovate or elongate trigonally ovate shells of tellinoid to donacoid shape.

\section{Genus Geloina Gray, 1842}

Type species. - Cyclas zeylanica Lamarck, 1806 (Recent; Sri Lanka), by subsequent designation by Gray (1847).

\section{Geloina amithoscutana sp. nov.}

Figures 3A-J, 4A-I

Types. - Holotype, left valve (Fig. 4A); locality MP 10; ONHM-F-4411a. Paratype 1, right valve (Fig. 4B); locality MP 10; ONHM-F-4411b. Paratype 2, right valve (Fig. 4H); locality MP 10; ONHM-F-4411c. Paratype 3, right valve (Fig. 4C); locality MP 10; ONHM-F-4411d. Paratype 4, fragmentary right valve (Fig. 4G); locality MP 6; ONHM-F-4412a. Paratype 5, fragmentary left valve (Fig. 4F); locality MP 6; ONHM-F-4412b. Paratype 6, right valve (Fig. 4D); locality MP 6; ONHM-F-4412c. Paratype 7, right valve (Fig. 4I); locality MP 6; ONHMF-4412d. Paratype 8, double-valved specimen (Fig. 3H); locality MP 6; ONHM-F-4412e. Paratype 9, doublevalved specimen (Fig. 3J); locality MP 6; ONHM-F4412f. Paratype 10, double-valved specimen (Fig. 3A); locality MP 1; ONHM-F-4413a. Paratype 11, doublevalved specimen, Fig. 3B; locality MP 6; ONHM-F4412g. Paratype 12, double-valved specimen (Fig. 3C); locality MP 6; ONHM-F-4412h. Paratype 13, doublevalved specimen (Fig. 3D); locality MP 1; ONHM-F4413b. Paratype 14, double-valved specimen (Fig. 3E); locality MP 10; ONHM-F-4411e. Paratype 15, doublevalved specimen (Fig. 3F); locality MP 10; ONHM-F4411f. Paratype 16, double-valved specimen (Fig. 3G); locality MP 1; ONHM-F-4413c. Paratype 17, doublevalved specimen (Fig. 3I); locality MP 10; ONHM-F4411g. Paratype 18, right valve (Fig. 4E); locality MP 10; ONHM-F-4411h.

Type horizon and locality. - Al-Khodh Formation, locality MP 10 (see Tab. 1).

Additional material. - Several hundred juvenile and adult left and right valves and articulated specimens, from the Al-Khodh Formation at localities MP 1, MP 2, MP 4, MP 5, MP 6, MP 7, MP 9 and MP 10.
Etymology. - Amithoscuta was the earliest mentioned unique name, used by Gaius Plinius Secundus ('Pliny the Elder'), for Muscat, the present-day capital of Oman (Forster 1844).

Diagnosis. - Small, up to $35 \mathrm{~mm}$ long, thick-shelled Geloina with short-subtrigonal, markedly inequilateral and prosogyrate shells; lowest point of shell distinctly anterior of mid-length. Lateral teeth and nymphs particularly strong and sturdy.

Description. - Shells very small for group, up to $35 \mathrm{~mm}$ in length (see Tab. 2 for measurements); thick and solid. Shell outline short subtrigonal, inaequilateral; umbo positioned distinctly behind mid-line; lowest point positioned at approximately one third from anterior end. Anterior-dorsal margin slightly incurved, almost straight; anterior and anterior-ventral margin well-rounded; posterior-ventral margin almost straight, subtly incurved in most specimens; posterior margin faintly rounded, almost straight, meeting posterior-ventral margin in well-rounded corner; posterior-dorsal margin almost straight, at blunt angles to posterior margin, forming a posterior shoulder. Shell distinctly inflated; umbos slightly protruding, moderately prosogyrate. Blunt posterior edge extending from umbo to posterior shoulder. No lunule, no escutcheon. Outside of shell ornamented with densely spaced, narrow, fairly regular commarginal costellae.

Hinge formula of right valve: AIII, AI, 3a, 1, 3b, PI, PIII. Cardinal teeth 1 and $3 \mathrm{~b}$ prominent, of almost equal size, high and narrow; cardinal tooth 3 a much weaker,

Table 2. Measurements of Geloina amithoscutana sp. nov., in $\mathrm{mm}$. Abbreviations: $\mathrm{H}$ - height; $\mathrm{L}$ - length; $\mathrm{T}$ - thickness.

\begin{tabular}{lccc}
\hline Specimen & L & H & T \\
\hline Holotype, ONHM-F-4411a (Fig. 4A) & 22 & 20 & 15 \\
Paratype 1, ONHM-F-4411b (Fig. 4B) & 18 & 16.5 & 12 \\
Paratype 2, ONHM-F-4411c (Fig. 4H) & 19 & 18 & 12.5 \\
Paratype 3, ONHM-F-4411d (Fig. 4C) & 18 & 16.5 & 12 \\
Paratype 8, ONHM-F-4412e (Fig. 3H) & 31 & 27 & 16.5 \\
Paratype 9, ONHM-F-4412f (Fig. 3J) & 29.5 & 26.5 & 16 \\
Paratype 10, ONHM-F-4413a (Fig. 3A) & 24 & 20 & 11.5 \\
Paratype 11, ONHM-F-4412g (Fig. 3B) & 25 & 19.5 & 13.5 \\
Paratype 12, ONHM-F-4412h (Fig. 3C) & 23 & 21.5 & 13.5 \\
Paratype 13, ONHM-F-4413b (Fig. 3D) & 34 & 31.5 & {$[16.5]$} \\
Paratype 14, ONHM-F-4411e (Fig. 3E) & 16 & 13.5 & 9.5 \\
Paratype 15, ONHM-F-4411f (Fig. 3F) & 18 & 16 & 11 \\
Paratype 16, ONHM-F-4413c (Fig. 3G) & 28 & 25 & 15 \\
Paratype 17, ONHM-F-4411g (Fig. 3I) & 14 & 12 & 8.5 \\
Paratype 18, ONHM-F-4411h (Fig. 4E) & 17.5 & 16.5 & 11 \\
\hline
\end{tabular}




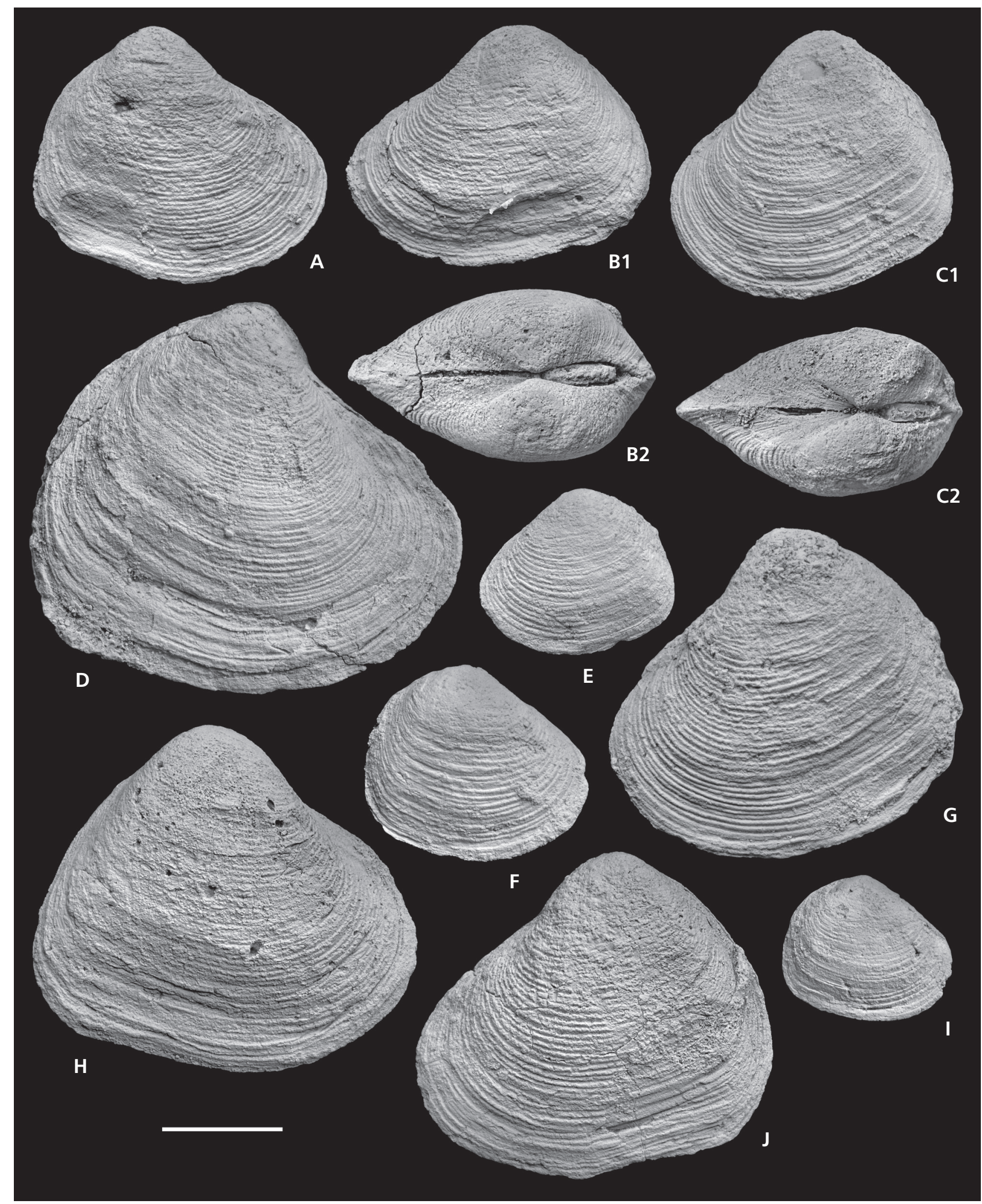

Figure 3. Cyrenidae from the Al-Khodh Formation. Geloina amithoscutana sp. nov. Outside view of several double-valved shells, displaying ontogenetic and intraspecific variability; A - paratype 10, locality MP 1, ONHM-F-4413a; B - paratype 11, locality MP 6, ONHM-F-4412g; C - paratype 12, locality MP 6, ONHM-F-4412h; D - paratype 13, locality MP 1, ONHM-F-4413b; E - paratype 14, locality MP10, ONHM-F-4411e; F - paratype 15, locality MP10, ONHM-F-4411f; G - paratype 16, locality MP 1, ONHM-F-4413c; H - paratype 8, locality MP 6, ONHM-F-4412e; I - paratype 17, locality MP10, ONHM-F-4411g; J - paratype 9, locality MP 6, ONHM-F-4412f. Scale bar $=10 \mathrm{~mm}$. 
more or less fused with anterior lateral tooth AIII, which forms a narrow, slightly elevated, incurved ridge close to anterior-dorsal shell margin. Anterior lateral tooth AI prominent, relatively long, markedly incurved. Posterior lateral tooth PI equally prominent; PIII faint and narrow. Hinge formula of left valve: AII, 2a, 2b, 4b, PII. Cardinal teeth $2 \mathrm{a}$ and $2 \mathrm{~b}$ prominent, of almost equal size, high and narrow; cardinal tooth $4 \mathrm{~b}$ much weaker. Later teeth AII and PII prominent. All hinge teeth smooth, not serrated. Nymphs prominent, high, but generally not protruding over shell margin. Pallial line entire, non-sinuate. Anterior and posterior adductor muscle scars of equal size, positioned directly below anterior and posterior ends of hinge plate, respectively. Posterior adductor muscle scar moderately deep; anterior adductor muscle scar shallow. Anterior pedal retractor muscle scar positioned on ventral surface of hinge plate; deep.

Remarks. - The species shows the general characteristics of Cyrenidae regarding shell shape, ornamentation and dentition. Characters that are of value for generic assignment are (1) the absence of a lunule and escutcheon; (2) smooth, non-serrated hinge teeth; (3) three entire, non-bifid cardinal teeth in each valve; (4) an entire, nonsinuate pallial line. The combination of these traits argues for a placement in Geloina. Huber (2015) records a weak pallial sinus for Geloina and depicts it for one species, while Morton (1976), in a detailed morphological-anatomical study of the genus, reported no pallial sinus. We thus regard the new species as falling within the limits of the variability of the genus.

At the specific level, the following features distinguish the new species from other fossil and modern representatives of Geloina. (1) The shells are rather thick and heavy, but small for the genus. Extant species reach adult sizes between 70 and $150 \mathrm{~mm}$ (Huber 2015). (2) The umbos are distinctly prosogyrate, and the shells markedly inequilateral, with a faint posterior shoulder; the lowest point of the shell is positioned distinctly anterior of midlength. (3) The lateral teeth and nymphs are unusually strong and prominent for the genus.

The wealth of material available makes it possible to display the intraspecific and ontogenetic variability of the species (Figs 3,4). Intraspecific variability is expressed in slightly variable length/height ratios, more or less inaequilateral shells and slightly wider or narrower umbos. Juvenile shells are usually strongly inaequilateral, have very low umbos and the ventral margin is not yet incurved (Fig. 3E, F, I).

\section{Genus Muscatella gen. nov.}

Type species. - Muscatella biszczukae sp. nov., by original designation herein.
Etymology. - From Muscat, the present-day capital of Oman.

Diagnosis. - Moderately large, up to $19.5 \mathrm{~mm}$ high Cyrenidae of regular elongate ovate, tellinoid shape. No lunule or escutcheon. Right valve hinge with three cardinal and four lateral teeth (AIII, AI, 3a, 1, 3b, PI, PIII); left valve hinge with three cardinal and two lateral teeth (AII, 2a, 2b, 4b, PII); all teeth smooth, not serrated. Cardinal teeth $1,2 \mathrm{a}, 2 \mathrm{~b}$ and $3 \mathrm{~b}$ prominent, incipiently bifid at the base. Nymphs elongate, low but prominent. Pallial line entire or very shallowly sinuate.

Remarks. - Muscatella shows the general characteristics of Cyrenidae regarding ornamentation and dentition, but is rather elongate in outline. Characters that are of value for generic assignment are (1) the elongate ovate shell outline, (2) the absence of a lunule and escutcheon; (3) smooth, non-crenulated hinge teeth; (4) three distinct, cardinal teeth in each valve, some of them incipiently bifid; (5) an entire or very shallowly sinuate pallial line. All single valves in our samples are either broken posteriorly or are too poorly preserved to determine the condition of the pallial line. However, if present, the sinus must be very shallow, judging from the specimen displayed in Fig. 5F.

The combination of these traits is unique among the Cyrenidae, and thus the new species described below accords with none of the genera previously included in the family. Only four genera assigned to the Cyrenidae are elongate ovate or elongate trigonally ovate in outline, i.e. have a tellinoid to donacoid shape. Among these, the type species of Palaeocene to Eocene western European Loxoptychodon Sandberger, 1872, Donacopsis Sandberger, 1872 and Tellinocyclas Dall, 1903 differ in outline shape from elongate ovate to trigonal donaciform, but all have distinctly serrated anterior lateral teeth and a sinuate pallial line. In Late Cretaceous Baidunoconcha $\mathrm{Gu}$ in $\mathrm{Gu} \& \mathrm{Yu}$, 1999 from the Nenjiang Formation of Jilin, northeastern China, the lateral teeth are serrated, and the conditions of the cardinal teeth and pallial line are unknown (not preserved in the type material).

\section{Muscatella biszczukae sp. nov.}

Figure $5 \mathrm{~A}-\mathrm{H}$

Types. - Holotype, fragmentary right valve (Fig. 5F); locality MP 14; ONHM-F-4414a. Paratype 1, fragmentary left valve (Fig. 5D); locality MP 13; ONHM-F-4415a. Paratype 2, fragmentary left valve (Fig. 5G); locality MP 14; ONHM-F-4414b. Paratype 3, double-valved specimen (Fig. 5B); locality MP 8; ONHM-F-4416a. Paratype 4, double-valved specimen (Fig. 5A); locality MP 8; ONHMF-4416b. Paratype 5, fragmentary right valve (Fig. 5H); 


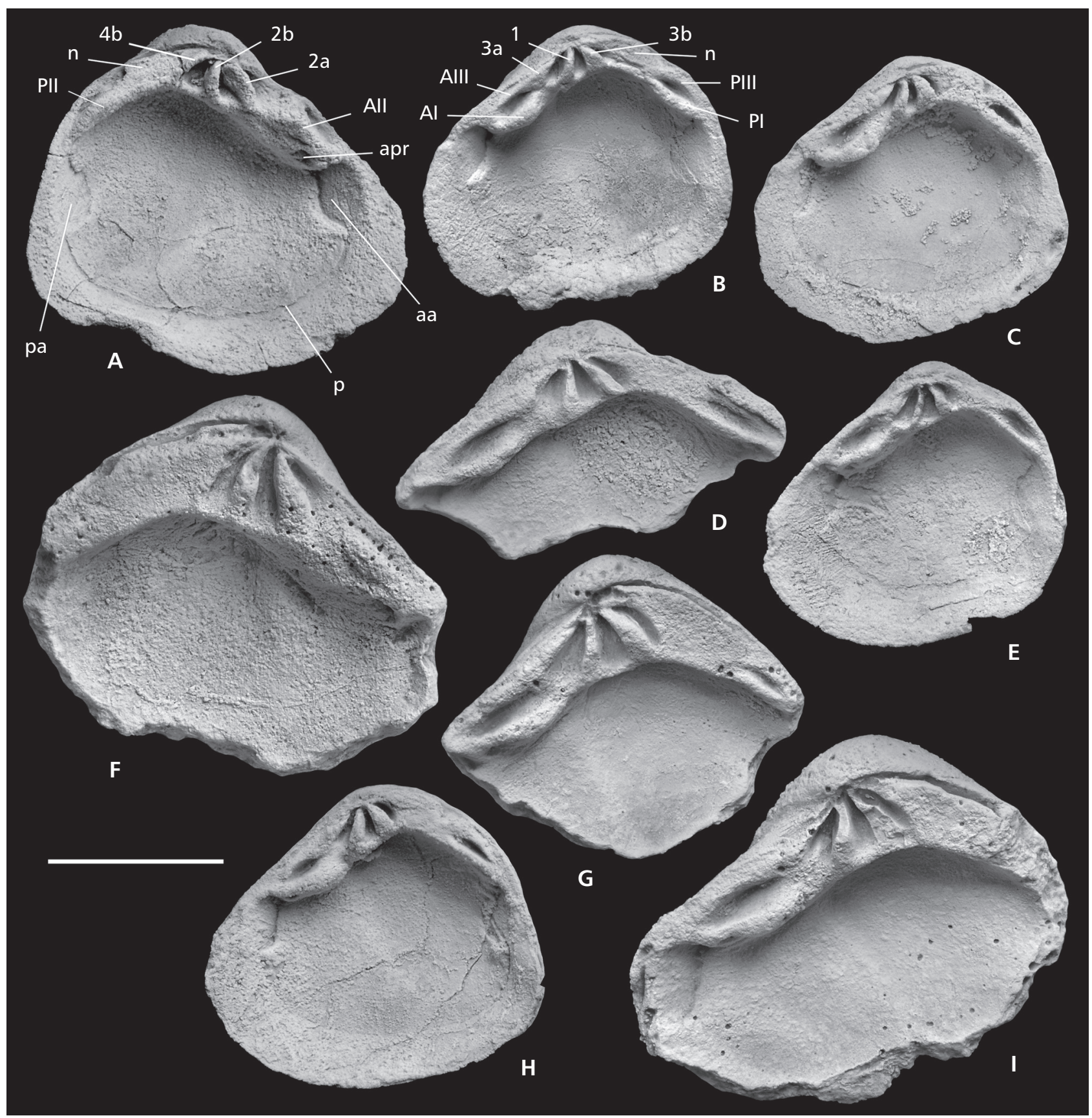

Figure 4. Cyrenidae from the Al-Khodh Formation. Geloina amithoscutana sp. nov. Inside views of several shells, displaying ontogenetic and intraspecific variability; A - left valve, holotype, locality MP10, ONHM-F-4411a; B - right valve, paratype 1, locality MP10, ONHM-F-4411b; C - right valve, paratype 3, locality MP10, ONHM-F-4411d; D - fragmentary right valve, paratype 6, locality MP 6, ONHM-F-4412c; E - right valve, paratype 18 , locality MP10, ONHM-F-4411h; F - fragmentary left valve, paratype 5, locality MP 6, ONHM-F-4412b; G - fragmentary right valve, paratype 4, locality MP 6, ONHM-F-4412a; H - right valve, paratype 2, locality MP10, ONHM-F-4411c; I - fragmentary right valve, paratype 7, locality MP 6, ONHM-F-4412d. Notation of hinge teeth is AIII, AI, 3a, 1, 3b, PI, PIII for right valves, and AII, 2a, 2b, 4b, PII for left valves. Abbreviations: aa - anterior adductor muscle scar; apr - anterior pedal retractor muscle scar; $\mathrm{n}$ - nymph; $\mathrm{p}$ - pallial line; pa - posterior adductor muscle scar. Scale bar $=10 \mathrm{~mm}$.

locality MP 14; ONHM-F-4414c. Paratype 6, fragmentary left valve (Fig. 5C); locality MP 13; ONHM-F-4415b. Paratype 7, double-valved specimen (Fig. 5E); locality MP 14; ONHM-F-4414d. Paratype 8, double-valved specimen (Fig. 5I); locality AK 51; ONHM-F-4433a.
Type horizon and locality. - Al-Khodh Formation, locality MP 14 (see Tab. 1).

Additional material. - Numerous additional doublevalved specimens and single valves from the Al-Khodh 
Formation at localities MP 8, MP 13, MP 14 and AK51.

Etymology. - Named after Magdalena Biszczuk, former GIS specialist at CASP, Cambridge, UK, who kindly prepared the map for Fig. 1, and many other maps before.

Diagnosis. - As for genus.

Description. - Shells up to $19.5 \mathrm{~mm}$ in height, moderately solid (see Tab. 3 for measurements). Shell outline ovate; umbo positioned slightly anterior to mid-line. Anteriordorsal margin faintly incurved; all other margins gently and regularly rounded. Shell weakly inflated; umbo faintly protruding, slightly prosogyrate. No lunule, no escutcheon. Outside of shell ornamented with densely spaced, narrow, fairly regular commarginal costellae.

Hinge formula of right valve: AIII, AI, 3a, 1, 3b, PI, PIII. Cardinal teeth 1 and $3 \mathrm{~b}$ prominent, of almost equal size, high triangular in shape, incipiently bifid at base; cardinal tooth 3a weak. Anterior lateral tooth AIII forming narrow, slightly elevated, almost straight ridge close to anterior-dorsal shell margin. Anterior lateral tooth AI prominent, markedly incurved. Posterior lateral tooth PI equally prominent; PIII faint and short. Hinge formula of left valve: AII, 2a, 2b, 4b, PII. Cardinal teeth $2 \mathrm{a}$ and $2 \mathrm{~b}$ prominent, of almost equal size, high triangular in shape, incipiently bifid at base; cardinal tooth 4 weak. All hinge teeth smooth, not serrated. Nymphs elongate and distinct, not protruding over shell margin. Pallial line either entire, or with a very short sinus. Anterior and posterior adductor muscle scars of equal size, positioned directly below anterior and posterior ends of hinge plate, respectively. Anterior pedal retractor muscle scar positioned on ventral surface of hinge plate.

Class Gastropoda Cuvier, 1795

Subclass Caenogastropoda Cox, 1960

Unassigned to superfamily sensu Bouchet et al. (2017)

Family Pseudomelaniidae R. Hoernes, 1884

Remarks. - The genus Pseudomelania Pictet \& Campiche, 1862 and consequently the family Pseudomelaniidae R. Hoernes, 1884 have been the subject of discussion since they were established. According to Pictet \& Campiche (1862, p. 266), Pseudomelania is 'turriculate, large, with a high spire, anomphalous, broad, with the ornament generally reduced to growth lines; the elliptic aperture possesses a rounded base and is adapically more or less acute angular, without a sinus or a canal. Without having internal plaits, the shape of the thick columella coincides with the general outline of the aperture. The labrum is smooth without being reinforced or dentate' (translated from French; slightly modified).
Table 3. Measurements of Muscatella biszczukae sp. nov., in mm. The value in squared brackets is an estimate for maximum length in M. biszczukae. Abbreviations: $\mathrm{H}$ - height; $\mathrm{L}$ - length; $\mathrm{T}$ - thickness.

\begin{tabular}{lccc}
\hline Specimen & L & H & T \\
\hline Paratype 3, ONHM-F-4416a (Fig. 5B) & 19 & 13 & 8 \\
Paratype 4, ONHM-F-4416b (Fig. 5A) & 12.5 & 8.5 & 5 \\
Paratype 5, ONHM-F-4414c (Fig. 5H) & {$[33]$} & 19.5 & $\backslash$ \\
Paratype 7, ONHM-F-4414d (Fig. 5E) & 20.5 & 13.5 & 8.5 \\
Paratype 8, ONHM-F-4433a (Fig. 5I) & 21.5 & 12 & 8 \\
\hline
\end{tabular}

Within the new genus, Pictet \& Campiche (1862) described three new species, Pseudomelania gresslyi (p. 266, pl. 70, figs 1, 2), P. jaccardi (p. 268, pl. 70, figs 3-5) and $P$. germani (p. 269, pl. 70, figs 6-8), which are all based on internal moulds, and, as a result, show only a few distinctive characters.

Pictet \& Campiche (1862) did not select a type species for Pseudomelania. Subsequently, P. Fischer (1887, p. 697) designated Chemnitzia normaniana d'Orbigny, 1851 (p. 40) as type species, which, however, was not originally included in Pseudomelania by Pictet \& Campiche (1862), and is thus not available as a type. After half a century of taxonomic confusion, Wenz (1938, p. 372) finally selected one of the three originally included species, Pseudomelania gresslyi, as type species of Pseudomelania. Among the species described by Pictet \& Campiche (1862), Pseudomelania gresslyi is most complete and thus definitely the primary choice for the type species. It differs from the other two species by its cyrtoconoid outline and convex whorls, of which the final one is about half the total height. Actually, these features do not fully agree with the general description of Pseudomelania given by Pictet \& Campiche (1862), but the moulds attributed to Pseudomelania jaccardi and P. germani are not adequately preserved for determining their generic position.

In this context, it is striking that Wenz (1938, p. 372) reproduced the well-preserved Chemnitzia heddingtonensis as figured by d'Orbigny (1851, pl. 244, fig. 3) (= Melania heddingtonensis J. Sowerby, 1813) to illustrate this genus. However, Gründel (2012) introduced the new genus Torusiana with Melania heddingtonensis J. Sowerby, 1813 as type species. According to Gründel (2012), the characteristic morphological feature of the new genus is a bulge at the adapical suture, delimited abapically by a constriction of the whorl surface. This adapical bulge is located in the continuation of a small expansion of the aperture. Due to the consistence of this morphological feature a connection with the soft-part anatomy can be assumed. It obviously represents an adapical widening of the mantle cave, which may have served the expelling of water loaded with faeces. There is no trace of the bulge on internal moulds. 


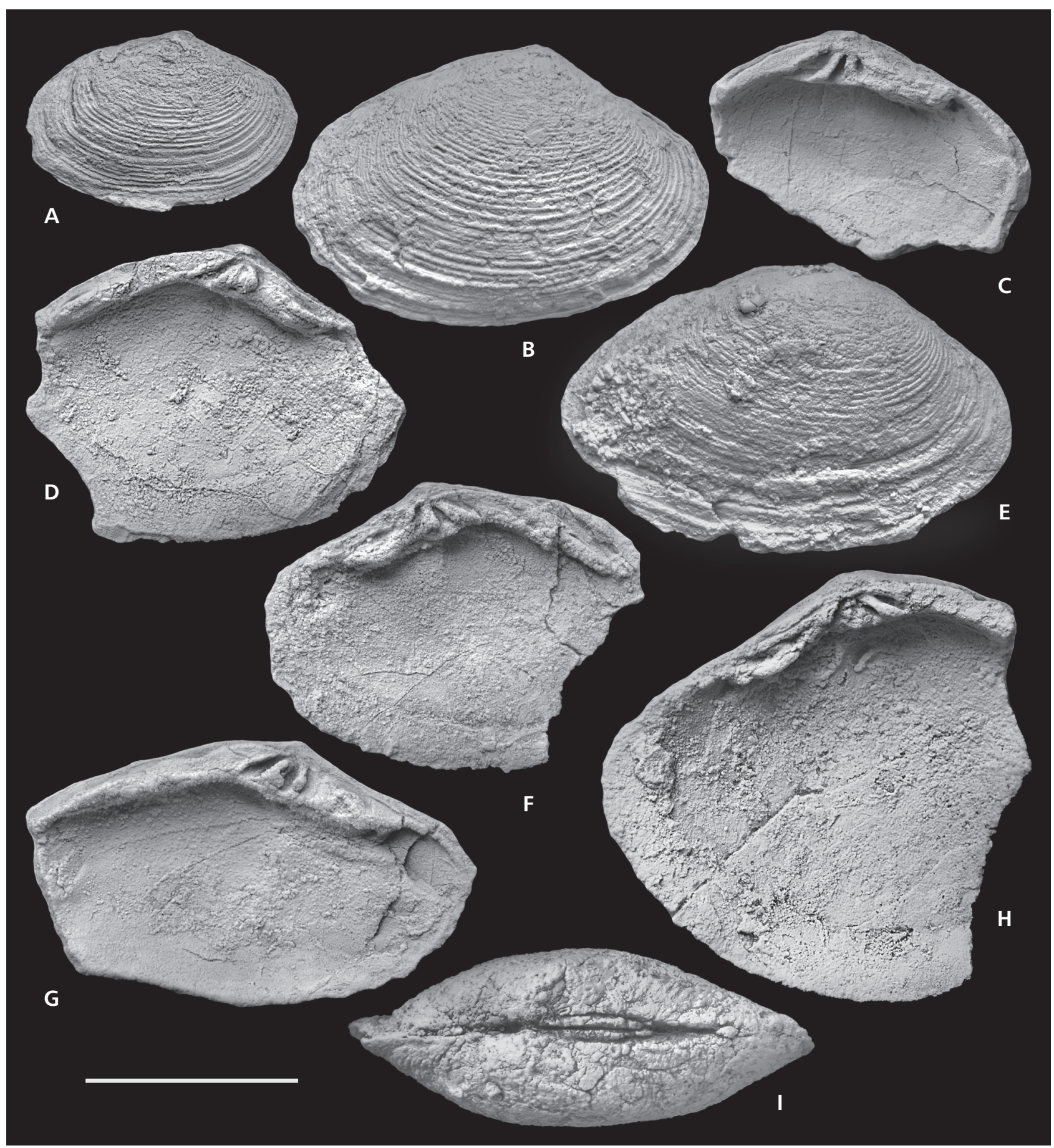

Figure 5. Cyrenidae from the Al-Khodh Formation. Muscatella biszczukae gen. et sp. nov.; A - subadult double-valved specimen, right-lateral view, paratype 4, locality MP 8, ONHM-F-4416b; B - double-valved specimen, right-lateral view, paratype 3, locality MP 8, ONHM-F-4416a; $\mathrm{C}$ - fragmentary left valve from inside, paratype 6 , locality MP 13 , ONHM-F-4415b; D - fragmentary left valve from inside, paratype 1 , locality MP 13, ONHM-F-4415a; E - double-valved specimen, right-lateral view, paratype 7, locality MP 14, ONHM-F-4414d; F - fragmentary right valve from inside, holotype, locality MP 14, ONHM-F-4414a; G - fragmentary left valve from inside, paratype 2, locality MP 14, ONHM-F-4414b; $\mathrm{H}$ - fragmentary right valve from inside, paratype 5, locality MP 14, ONHM-F-4414c; I - double-valved specimen, view from top, paratype 8 , locality AK 51, ONHM-F-4433a. Scale bar $=10 \mathrm{~mm}$.

The adapical bulge had already been mentioned by J. Sowerby (1813) in the original description of Melania lineata ('a very slight contraction towards the upper part of each whorl'), and in fact, the majority of species hitherto assigned to Pseudomelania shows this feature. Ten Jurassic species described by d'Orbigny under Chem- 
nitzia and assigned to Pseudomelania by Fischer \& Weber (1997), as well as Pseudomelania feruglioi Ferrari, 2013 from the Early Jurassic of Argentina, were included in Pseudomelania by Gründel (2012).

\section{Genus Subtemenia gen. nov.}

Type species. - Paryphostoma morgani Douvillé, 1904 (p. 328; Maastrichtian; Iran), by original designation herein.

Etymology. - From the Latin word for thread, subtemen, referring to the linear suture.

Diagnosis. - Shells large, broadly turriculate, with generally flat whorls and linear sutures. Last whorl high, with broadly rounded or subangular periphery. Growth lines slightly opisthocyrt. Aperture broadly rounded at the base and angular adapically, with a moderately broad and reinforced outer lip.

Remarks. - Following the attribution of the type species by Douvillé (1904), Subtemenia gen. nov. is assigned to the Pseudomelaniidae. Douvillé (1904) stated: 'We provisionally unite under the name (pseudomelaniids) all these elongate marine shells with an entire aperture, which resemble melaniids in shape.' [translated from French]

The broad turriculate outline, the flat to moderately convex whorls, the proportions of the last whorl, the opisthocyrt growth lines, which indicate a slightly sinuous labrum, and, last but not least, the large size support the systematic position of Subtemenia gen. nov. In contrast to Pseudomelania, Subtemenia possesses no subsutural bulge. The specimens figured by Douvillé (1904) show a change of morphology during ontogeny. The whorl flank is delimited towards the base by a rounded periphery in smaller specimens, which becomes more or less angular in large ones.

Douvillé (1904) originally assigned his new species to Paryphostoma Bayan, 1873, which was established to replace Keilostoma Deshayes, 1848, according to Bayan (1873) because of the great similarity of this name with Chilostoma Fitzinger, 1833 (Helicidae). Cossmann (1921) followed Bayan in his argumentation. However, since the spelling of the two names is significantly different, Paryphostoma Bayan, 1873 is an unnecessary replacement name, and thus invalid. This was already acknowledged by Wenz (1939), who treated Paryphostoma as a junior synonym of Keilostoma. Members of the latter genus are usually small to very small and possess an almost circular aperture in which the outer lip is heavily reinforced.

\section{Subtemenia morgani (Douvillé, 1904)}

Figure $6 \mathrm{~A}-\mathrm{F}$

\author{
*1904 Paryphostoma Morgani n. sp.; Douvillé, p. 328, pl. \\ 46, figs $12-17$. \\ 1928 Keilostoma (Paryphostoma) morgani. - Lees, p. 651. \\ 1929 Paryphostoma morgani. - Kühn, p. 19. \\ 1995 Paryphostoma morgani Douvillé. - Smith et al., p. 119.
}

Material. - Several fragments have been extracted from sandstone and granule-sized conglomerate of the Al-Khodh Formation at localities AK 33 [ONHM-F-4420a, b], AK 51 [ONHM-F-4422a-d],MP2[1 spec.],MP5[ONHM-F-4434a], MP 7 [ONHM-F-4435a] and MP 13 [ONHM-F-4421a].

Description. - Apical angle of shell approximately $15^{\circ}$. Body whorl moderately convex; earlier whorls flat; sutures hardly impressed. Sculpture consisting of sporadic remains of nodose spiral threads, obviously originally covering the entire surface. Last whorl showing orthocline impressions of growth rugae. Whorl sides passing smoothly into rounded base. Base of aperture rounded. Adapical angle of aperture approximately $50^{\circ}$. Columella low, concave. Parietal lip slightly expanded and reinforced. Margin of labrum acute. Measurements are listed in Tab. 4.

Remarks. - In the specimens figured by Douvillé (1904), the sculpture of spiral threads is well-preserved. The large specimen (figs 14, 15) and one of the smaller ones (fig. 13) possess a blunt peripheral angle. In the small specimen of figures 12 and 16, the periphery is evenly rounded, as in most of the specimens collected in Oman. The slight variability with regard to the shape of the whorl periphery is attributed to intraspecific variability.

Occurrence. - Paryphostoma morgani was originally described from Maastrichtian strata in Lorestan Province, western Iran (Douvillé 1904). The species has previously been recorded from the Maastrichtian of Oman, from highly diverse shallow marine assemblages in the area of Al Ayn (Lees 1928, Kühn 1929, Smith et al. 1995).

Superfamily Cerithioidea Fleming, 1822

Family Hemisinidae P. Fischer \& Crosse, 1891

\section{Genus Stephaniphera gen. nov.}

Type species. - Stephaniphera coronata gen. et sp. nov.

Etymology. - From the Greek words for crown and carrying, stephanos and phero, referring to the ornamentation of the shells.

Diagnosis. - Shell large (up to $45 \mathrm{~mm}$ high); whorls high and cylindrical in outline. Early ontogenetic whorls possessing subsutural collar; later ones possessing broad, depressed ramp with strong nodes at its outer margin. 


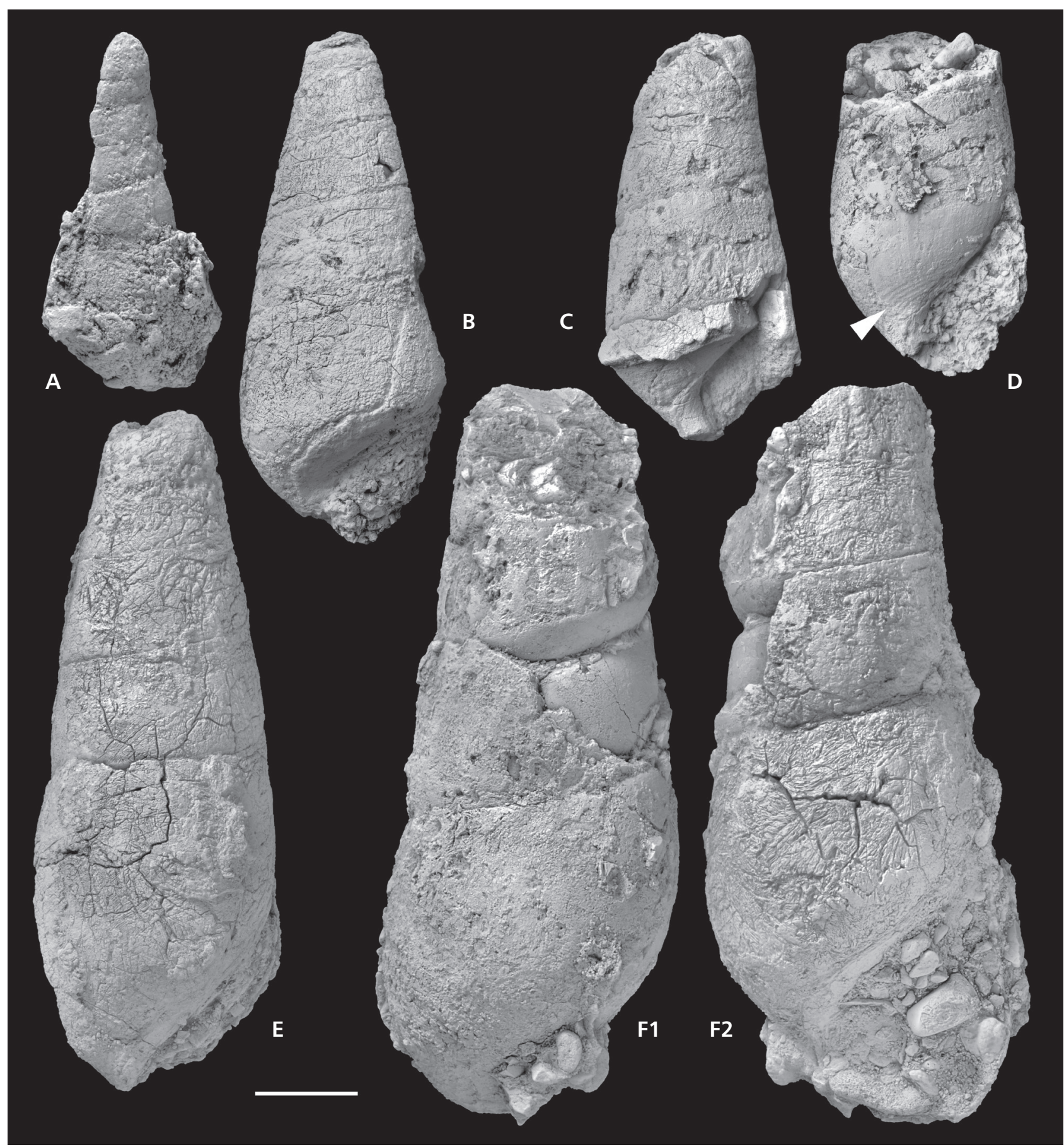

Figure 6. Pseudomelaniidae from the Al-Khodh Formation. Subtemenia morgani (Douvillé, 1904); A - apical fragment, locality MP 5, ONHM-F-4434a; B - almost complete specimen from front, locality AK 51, ONHM-F-4422a; C - fragmentary specimen from front, locality AK 51, ONHM-F-4422b; D - fragmentary specimen from front, with delicate spiral furrows on adabical part of last whorl indicated by white arrow, locality AK 51, ONHM-F-4422c; E - fragmentary specimen from front, locality AK 33, ONHM-F-4420a; F - fragmentary specimen from back (F1) and front (F2); locality MP 7, ONHM-F-4435a. Scale bar $=10 \mathrm{~mm}$.

Aperture high, narrow elliptic. Columellar lip concave, truncated towards the deep basal notch.

Remarks. - Stephaniphera is distinguished from the Purpurinidae Zittel by its truncated columella, the deep basal notch and the broad subsutural ramp. As in Stephaniphera gen. nov., a truncated columella and a deep basal notch are morphological characters of Hemisinus and other genera combined in the subfamily Hemisininae P. Fischer \& Crosse, 1891, which was treated as a syno- 
Table 4. Measurements of Subtemenia morgani (Douvillé, 1904), in mm. Abbreviations: AA - apical angle; $\mathrm{H}$ - height; $\mathrm{HB}$ - height of last whorl; W - width.

\begin{tabular}{lcccc}
\hline Specimen & H & HB & W & AA \\
\hline ONHM-F-4434a (Fig. 6A) & 17 & 12.5 & 8 & 15 \\
ONHM-F-4422a (Fig. 6B) & 49 & 24.5 & 19.5 & 25 \\
ONHM-F-4422b (Fig. 6C) & 39 & 15 & 19 & 21 \\
ONHM-F-4422c (Fig. 6D) & 33 & 16.5 & 18 & $\backslash$ \\
ONHM-F-4420a (Fig. 6E) & 61.5 & 38 & 25.5 & 26 \\
ONHM-F-4435a (Fig. 6F) & 71.5 & 42.5 & 29 & 17 \\
\hline
\end{tabular}

nym of Thiaridae Gill, 1871 by Bouchet \& Rocroi (2005). Recently, Hemisinidae P. Fischer \& Crosse, 1891 was reestablished at family rank by Bouchet et al. (2017). The morphological features show a close affinity of Stephaniphera to Hemisinus Swainson, 1840 and other related genera. Pyrgulifera Meek, 1871, differs by its almost circular aperture and a small basal notch.

\section{Stephaniphera coronata gen. et sp. nov.}

Figure $7 \mathrm{~A}-\mathrm{F}$

Types.-Holotype(Fig.7A); localityAK51;ONHM-F-4417a. Paratype 1 (Fig. 7B); locality AK 51; ONHM-F-4417b. Paratype 2 (Fig. 7C); locality MP 14; ONHM-F-4418a. Paratype 3 (Fig. 7D); locality AK 51; ONHM-F-4417c. Paratype 4 (Fig. 7E); locality AK 51; ONHM-F-4417d. Paratype 5 (Fig. 7F); locality AK 51; ONHM-F-4417e.

Type horizon and locality. - Al-Khodh Formation, locality AK 51 (see Tab. 1).

Additional material. - Several specimens from the AlKhodh Formation at locality AK 51; ONHM-F-4417f-j.

Etymology. - From the Latin word for crowned, coronatus, referring to the row of prominent nodes on the outer margin of the subsutural ramp.

Diagnosis. - As for genus.

Description. - Shells high with last whorl taking approximately two thirds of total height. Early whorls almost flat, with inclined subsutural collar, later passing into broad, depressed ramp. Ramp delimited by distinct edge with large rounded, abapically extended nodes. Nodes decreasing in size at approach to aperture; simultaneously, distance between nodes reduced to almost zero. Shell with distinct growth lines. Aperture high, narrow elliptic; outer margin sharp. Columellar lip concave, slightly expanded, abapically truncated, leaving space for deep basal notch. Measurements are listed in Tab. 5.
Table 5. Measurements of Stephaniphera coronata sp. nov., in mm. Abbreviations: AA - apical angle; $\mathrm{H}$ - height; $\mathrm{HB}$ - height of last whorl; W-width.

\begin{tabular}{lcccc}
\hline Specimen & H & HB & W & AA \\
\hline Holotype, ONHM-F-4417a (Fig. 7A) & 42 & 25 & 26.5 & 76 \\
Paratype 1, ONHM-F-4417b (Fig. 7B) & 37.5 & 21 & 25 & 68 \\
Paratype 2, ONHM-F-4418a (Fig. 7C) & 26.5 & 20.5 & 15 & 53 \\
Paratype 3, ONHM-F-4417c (Fig. 7D) & 43 & 27 & 30.5 & 88 \\
Paratype 4, ONHM-F-4417d (Fig. 7E) & 44 & 29 & 33 & 85 \\
Paratype 5, ONHM-F-4417e (Fig. 7F) & 39 & 25 & 25 & $\backslash$ \\
\hline
\end{tabular}

Remarks. - The sculpture of Stephaniphera coronata gen. et sp. nov. is comparable to that of Chemnitzia inflata d'Orbigny, 1842. Despite the small basal notch in the type species (see Roman \& Mazeran 1920, Kollmann 2005), the figure by d'Orbigny (1842, p. 156, fig. 2) shows a rounded base. This obviously motivated Roman \& Mazeran (1920) and Delpey (1937) to assign Chemnitzia inflata to Microschiza Gemmellaro, 1878 and to Coronatica Blanckenhorn, 1927, respectively. The species differs from Stephaniphera coronata gen. nov. sp. nov. by its oblique columella, which is not truncated but decreases in thickness towards the base. Kollmann (2005) attributed Chemnitzia inflata to the Melanopsidae genus Megalonoda Kollmann, 1984 (see also Neubauer et al. 2016).

Family Turritellidae Lovén, 1847

\section{Genus Torquesia Douvillé, 1929}

Type species. - Turritella granulata J. de C. Sowerby, 1827 (Eocene, England), by subsequent designation; Opinion 493 (1957).

Remarks. - Torquesia Douville 1929 is distinguished from Turritella by the deep sinus of the growth lines, with its vertex around mid-whorl and points of inflection below and above. The whorls are flat with beaded spiral cords, of which the adapical one ist most prominent.

\section{Torquesia contumescens (Stoliczka, 1868)}

Figure 8A-D

1868 Turritella contumescens, Stoliczka, p. 221, pl. 16, fig. 17; pl. 19, fig. 17.

Material. - Four fragmentary specimens from the Jafnayn Limestone Formation at locality Fanja Back; ONHM-F4423a-d.

Description. - Shell narrow turriculate. Growth lines forming deep sinus at mid-whorl, with points of in- 


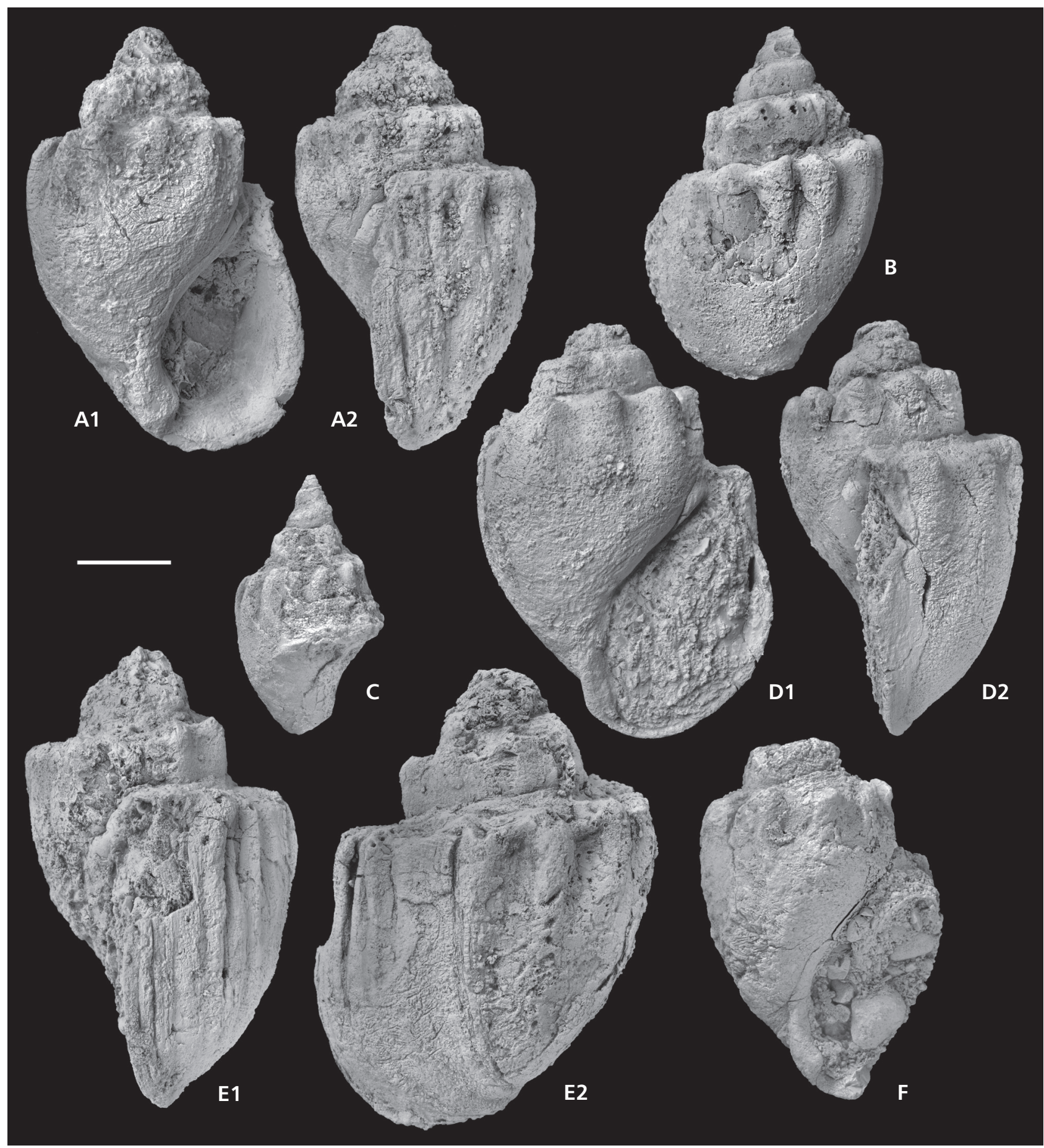

Figure 7. Hemisinidae from the Al-Khodh Formation. Stephaniphera coronata gen. et sp. nov.; A - adult specimen from front (A1) and right (A2), holotype, locality AK 51, ONHM-F-4417a; B - subadult specimen from back, paratype 1, locality AK 51, ONHM-F-4417b; C - fragmentary juvenile from front, paratype 2, locality MP 14, ONHM-F-4418a; D - adult specimen from front (D1) and right (D2), paratype 3, locality AK 51, ONHM-F-4417c; E - adult specimen from right (E1) and back (E2), paratype 4, locality AK 51, ONHM-F-4417d; F - fragmentary adult specimen from front, paratype 5, locality AK 51, ONHM-F-4417e. Scale bar $=10 \mathrm{~mm}$.

flection adapically and abapically. Whorls slightly depressed around vertex of growth lines. Four specimens representing different growth stages with changing sculpture. Whorl heights of smallest specimen between
7 and $10 \mathrm{~mm}$, with sculpture consisting of two prominent beaded cords adapically, two less prominent ribs and threads on depressed portion, and two stronger cords abapically, the lower one located at margin towards flat 
base. At whorl height of approximately $15 \mathrm{~mm}$, broad, pillow-like nodes developing at the two adapical cords. Numerous weak ribs and threads developed in median concave zone; abapically, numerous beaded threads occurring between the two cords. Two adapical cords transforming into prominent adapical bulge at whorl height of $20 \mathrm{~mm}$. Numerous threads of variable strength covering space between bulge and single cord delimiting the base.

Measurements: $\mathrm{H}$ (incomplete $)=26.5-44 \mathrm{~mm} ; \mathrm{HB}=$ $11.5-18 \mathrm{~mm} ; \mathrm{W}=12.5-20 \mathrm{~mm} ; \mathrm{AA}=10-11^{\circ}$.

Remarks. - The specimens are assigned to Torquesia contumescens because of the deep sinus of the growth lines and the prominent adapical bulge developing from two cords of earlier whorls. The two figures of a single whorl provided by Stoliczka (1868) show three beaded cords, a smooth cord at the abapical suture and threads between them. The figure by Stoliczka agrees in general with that of the medium-size whorls described here.

Occurrence. - This species was originally described by Stoliczka (1868) from the Ariyalur Group in the surroundings of Ariyalur in Tamil Nadu, southeastern India. An additional record by Dartevelle \& Brebion (1956) comes from Gabon, West Africa.

Family Thiaridae Gill, 1871

\section{Genus Cosinia Stache, 1880}

Type species. - Paludomus cosinensis Stache in Sandberger, 1871 (Cretaceous; Slovenia), by subsequent designation by Cossmann (1909).

\section{Cosinia sp.}

Figure 9B

Material. - A single specimen from the Jafnayn Limestone Formation at locality Fanja Back; ONHM-F-4424a.

Description. - Specimen incomplete, of medium size, almost as broad as high. Whorls generally convex, with moderately inclined narrow adapical ramp. Last whorl comprising approximately two thirds of total height. Remains of sculpture of delicate spiral threads preserved at base. Growth lines around the centre yielding evidence of narrow basal notch. Aperture narrow elliptic with straight parietal lip and concave columella.

Measurements: $\mathrm{H}=15.3 \mathrm{~mm} ; \mathrm{HB}=9 \mathrm{~mm} ; \mathrm{W}=$ $12.2 \mathrm{~mm} ; \mathrm{AA}=75^{\circ}$.

Remarks. - Stache (1889) described several species under Cosinia. As in the fragmentary remains of the present specimen, the sculpture consists of delicate spiral threads. However, the whorls of the species attributed to Cosinia by Stache possess a broad adapical shoulder (not a narrow, inclined ramp as in Cosinia sp.); the profile of the transition to the abapical part of the whorls varies from angular to rounded in Stache's material. Because of their similar morphologies the species described by Stache are regarded as varieties of Cosinia bicincta Stache, 1889 herein. The basal notch was figured in pl. 1, figs 21a and $25 \mathrm{a}$.

Stache (1889) attributed Cosinia to his newly established subfamily Stomatopsinae. Indeed, Cosinia possesses the narrow basal notch that is characteristic of this subfamily, which corroborates this assignment. Bouchet \& Rocroi (2005) considered the Stomatopsinae to be synonymous with the Melanopsidae H. Adams \& A. Adams, 1854. Following remarks by Neubauer (2016), Bouchet et al. (2017) re-established Stomatopsinae and moved it to the Thiaridae.

Family Batillariidae Thiele, 1929

\section{Genus Pyrazus Montfort, 1810}

Type species. - Pyrazus baudini Montfort, 1810 (Recent; Australia), by original designation [= Pyrazus ebeninus (Bruguière, 1792)].

\section{Pyrazus sp.}

Figure 9A

Material. - A single specimen from the Jafnayn Limestone Formation at locality Fanja Back; ONHM-F-4425a.

Description. - Shell narrow turriculate. Ontogenetically early whorls convex with narrow subsutural collar. Sculpture incompletely preserved; consisting of 10 orthocline collabral ribs, aligned on successive whorls and crossed by three spiral threads. In ontogenetically later whorls, strong nodes developing at crossing points of collabral ribs with external angle of collar; spiral threads distributed all over the whorls. Breadth of subsutural collar and its angle towards shell axis increasing on final whorl; nodes becoming more prominent. Nodes decreasing in number and size towards aperture; finally replaced by squamous ledge. Abapical part of last whorl fragmentary. Preserved part of columellar lip strongly reinforced. Expansion of peristome triangular; located at margin towards (not preserved) parietal lip, enclosing narrow adapical canal. Growth lines opisthocyrt. Ventrolateral varix opposite aperture not elevated above shell surface, but contrasting with growth lines due to its lighter colour.

Measurements: $\mathrm{H}=41.5 \mathrm{~mm} ; \mathrm{HB}=22 \mathrm{~mm} ; \mathrm{W}=$ $17.5 \mathrm{~mm} ; \mathrm{AA}=24^{\circ}$. 


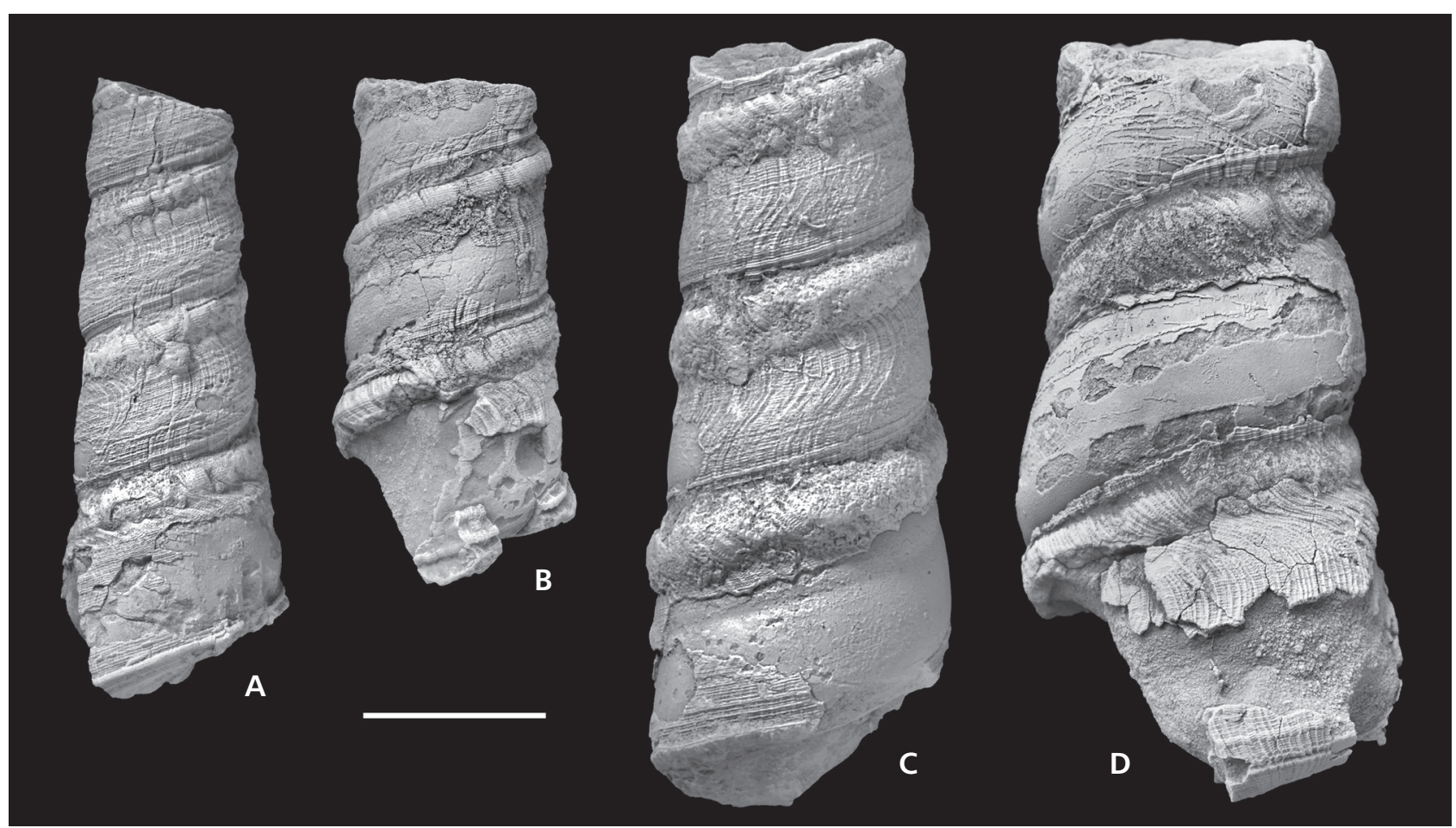

Figure 8. Turritellidae from the Jafnayn Limestone Formation at locality 'Fanja Back'. Torquesia contumescens (Stoliczka, 1868); A - ONHM-F4423a; B - ONHM-F-4423b; C - ONHM-F-4423c; D - ONHM-F-4423d. Scale bar $=10 \mathrm{~mm}$.

Remarks. - The taxonomic distinction and systematic position of Pyrazus were the subject of extensive discussion (see Ozawa et al. 2009 and references therein). According to Ozawa et al. (2009), who provided the latest opinion on this matter, Pyrazus belongs to the family Batillariidae. It is distinguished from members of the Potamididae by its straight columella lacking twists or folds, and the absence of varices on the spire whorls (Ozawa et al. 2009). Pyrazus differs from other batillariid genera by the presence of a ventrolateral varix on the final whorl. Both Pyrazus and Pyrazisinus Heilprin, 1887 possess an adapical canal, but are distinguished by the shape of their whorls, which are strongly convex with deep sutures in Pyrazisinus, but angular with moderately deep sutures in Pyrazus.

Originally, the genus Pyrazus comprised only extant species (see Healy \& Wells 1998). However, Marwick (1929) and Powell \& Bartrum (1929) described three new Pleistocene species from New Zealand under this generic name (Pyrazus weitemaetensis, P. consobrinus and $P$. sutherlandi). Of these, $P$. weitemaetensis was later attributed to the cerithiid genus Gourmya by Houbrick (1984), and Beu et al. (2004) transferred all three species to the Potamididae genus Terebralia Swainson, 1840. However, based on the figures published by Powell \& Bartrum (1929), Ozawa et al. (2009) inferred close affinities of Pyrazus consobrinus and P. sutherlandi with Pyrazus ebeninus (Bruguière, 1792), the type species of the genus. The new record from the Jafnayn Limestone Formation (if not a case of convergence) considerably extends the range of the genus into at least the Palaeocene, if not the latest Cretaceous (see discussion below).

Family Ampullinidae Cossmann in Cossmann \& Peyrot, 1919

\section{Genus Amaurellina Bayle in P. Fischer, 1885}

Type species. - Ampullaria spirata Lamarck, 1804 (Eocene; France), by monotypy.

\section{Amaurellina nuttalli (Douvillé, 1929)}

Figure 9C

*1929 Naticina nuttalli; Douvillé, p. 59, pl. 9, figs 25-28.

Material. - A single specimen from the Jafnayn Limestone Formation at locality Fanja Back; ONHM-F-4426a.

Description. - Shell consisting of convex whorls with narrow subsutural ramp. Suture impressed. Last whorl accounting for approximately two thirds of total height, almost globular in shape. Aperture elongate elliptical; columellar lip thin, moderately convex. Strong lamella extending from base into umbilicus.

Measurements: $\mathrm{H}=21.5 \mathrm{~mm} ; \mathrm{HB}=15.5 \mathrm{~mm} ; \mathrm{W}=$ $17 \mathrm{~mm} ; \mathrm{AA}=90^{\circ}$. 
Remarks. - Douvillé (1929) figured several specimens of variable size of this species. In small specimens, the umbilicus is narrow with a rounded margin (Douvillé 1929, fig. 28), while fig. 26 shows a well-developed lamella extending into the umbilicus as is recorded here. This morphological character, the high spire and the broad aperture suggest assignment to Amaurellina, and distinguish Amaurellina nuttalli from other Naticoidea.

Occurrence. - This species was originally described from the Maastrichtian or Danian 'Cardita beaumonti Beds' of Balochistan Province in southwestern Pakistan (Douvillé 1929; see Crame 2013 and discussion below).

Infraclass Euthyneura

Order Ringiculimorpha

Superfamily Ringiculoidea Philippi, 1853

Family Ringiculidae Philippi, 1853

\section{Ringiculidae sp. indet.}

Figure 9D

Material. - A single specimen from the Al-Khodh Formation at locality MP 7; ONHM-F-4427a.

Description. - Shell outline elliptic. Spire low. Earliest preserved whorls moderately convex, with narrow, inclined subsutural ramp and remains of delicate collabral ribs. Traces of delicate spiral threads are preserved on last whorl. Aperture high elliptical, with narrow adapical channel. Narrow basal channel only partly preserved. Callous inner lip bearing two blunt columellar plaits and a thin, incompletely preserved parietal plait or tooth. Labrum not preserved.

Measurements: $\mathrm{H}=15.5 \mathrm{~mm} ; \mathrm{HB}=12.5 \mathrm{~mm} ; \mathrm{W}=$ $10 \mathrm{~mm} ; \mathrm{AA}=40^{\circ}$.

Remarks. - Due to the rather poor preservation of the single specimen from Oman, we refrain from generic or specific assignment. Ringinella acuminata Stoliczka, 1868 from the Ariyalur Group at Comarapolliam near Ariyalur in Tamil Nadu, southeastern India, differs by its higher spire 'consisting of numerous, slightly convex volutions' (Stoliczka 1868 , p. 423). Its variability, however, is unknown.

\section{Discussion}

\section{Palaeobiogeography and biostratigraphy}

Today, the Arabian Peninsula has a hot, arid climate and thus has hardly any lakes or permanent rivers. As a result, the peninsula is devoid of any larger freshwater bivalves, and forms a distribution gap between the Nile bioprovince of Afrotropica and the Middle East bio-province of Palaearctica (Neubert 1998, Graf \& Cummings 2007, Bogan 2008). During the latest Pleistocene, short-lived, shallow lakes existed in the Rub'al Khali desert of Saudi Arabia, approximately $150 \mathrm{~km}$ north of the present-day border to Yemen (McClure 1984). Fossil freshwater molluscs from these lakes had first been reported by Philby (1933) and later figured by McClure (1984). These include the only previous record of unionids from the Arabian Peninsula we are aware of, Unio terminalis Bourguignat, 1852. The status and (current) distribution of this species in the Middle East are unresolved (Araujo et al. 2018), but it is part of a clade of Western Palaearctic origin, and thus certainly not closely related to the fossil unionids from Al-Khodh.

At the time of deposition of the Al-Khodh Formation, the Arabian Plate was still part of Africa. Rifting of the Red Sea had not started until the late Oligocene, when also the seaway connecting the Mediterranean Sea and the Indian Ocean started to close (e.g. Harzhauser et al. 2002, Bosworth 2015). During the latest Cretaceous, the study area in Oman was situated on the north coast of a large island at the eastern margin of a wide epicontinental sea covering large areas of the present-day Arabian Peninsula, and was facing the Tethys Ocean to the northeast (e.g. Scotese 2013).

The fossil unionids described herein thus possibly had closer affinities to the African freshwater fauna than to the Asian biota. Van Damme et al. (2015) recently reviewed the African Mesozoic fossil record of the Unionida. All species described are significantly older than the fossils from Oman, the youngest ones being Coniacian to Santonian in age. Due to both the limited preservation of our material and the poor fossil record of unionids in the wider region, the specimens from Oman currently have no implications beyond adding a dot - though a valuable one - on the map.

A look at the freshwater to brackish-water Cyrenidae is more informative. The extant freshwater genus Corbicula Megerle von Mühlfeld, 1811, includes several invasive species and has a near-global distribution. On the Arabian Peninsula, Corbicula is represented by a single native species, Corbicula fluminalis (O.F. Müller, 1774) (synonym: Corbicula purpurea Prime, 1867; see Huber 2015), in coastal Saudi Arabia between Kuwait and Qatar (Neubert 1998). The same species occurred in short-lived shallow lakes in the Rub'al Khali desert in southern Saudi Arabia, not far from the border to Yemen, during the latest Pleistocene (listed as Corbicula crassula by McClure 1984). Although cyrenid phylogeny is still poorly resolved (e.g. Graf 2013, Huber 2015), it is evident that the Quaternary Corbicula fluminalis and the fossil species from $\mathrm{Al}$ Khodh are only distantly related. 


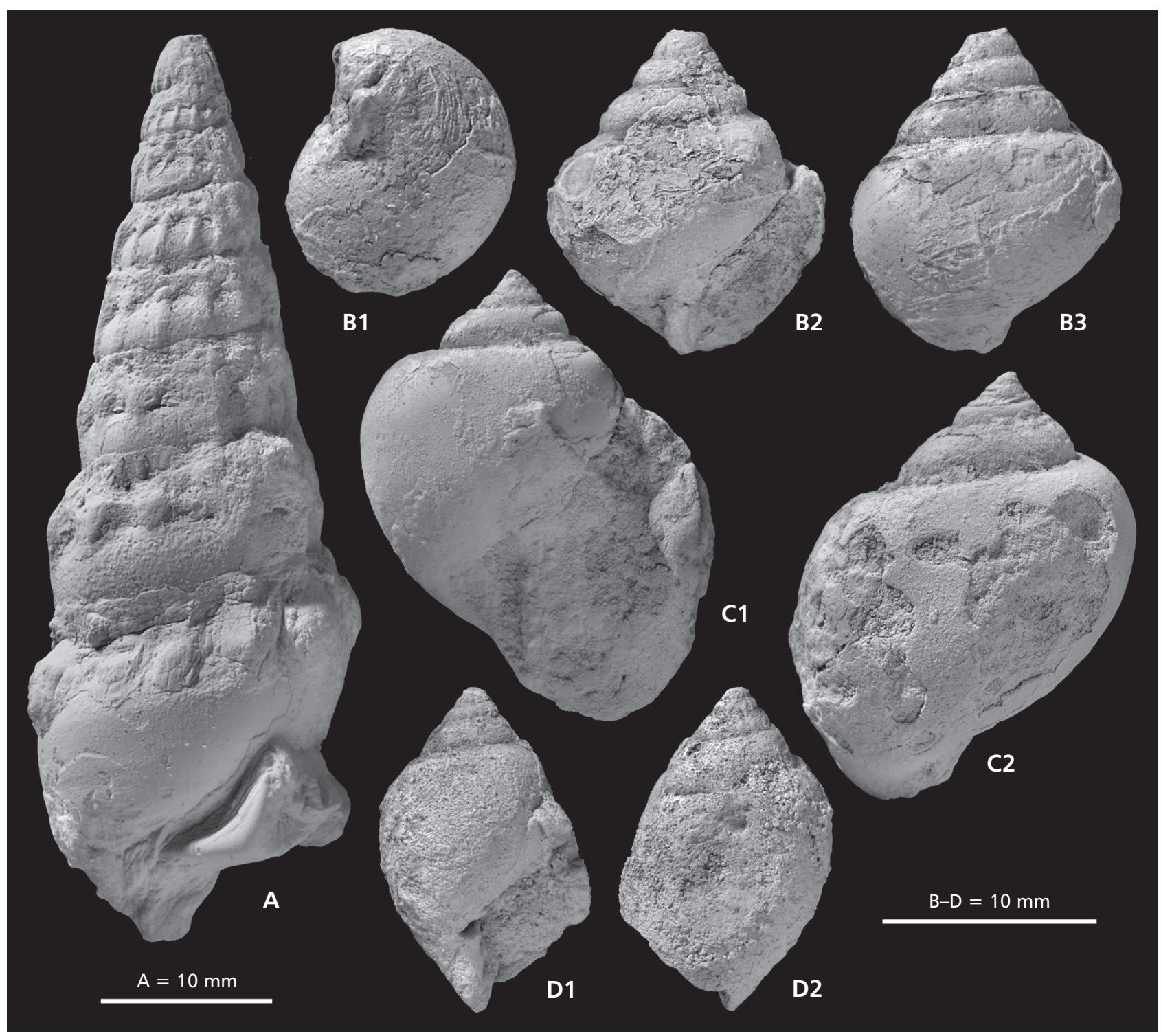

Figure 9. Molluscs from the Jafnayn Limestone Formation at locality 'Fanja Back'. • A - Pyrazus sp.; ONHM-F-4425a. • B - Cosinia sp.; ONHM-F-4424a. • C - Amaurellina nuttalli (Douvillé, 1929); ONHM-F-4426a. • D - Ringiculidae gen. et sp. indet.; ONHM-F-4427a. Scale bars = 10 mm.

However, Cyrenidae have a fossil record dating back to the Early Jurassic and were widespread in Europe and Asia during the Cretaceous (Casey 1955, Keen \& Casey 1969), although, as is common for fresh- to brackish-water taxa (e.g. Dunhill et al. 2014), their fossil record is patchy.

Necessarily, the immediate phylogenetic relationships of the newly established genus Muscatella are enigmatic. Fossil bivalves assigned to Geloina, however, occur throughout the Cenozoic. The earliest representative, Geloina rutoti (Cossmann, 1908) comes from the Danian (Palaeocene) of Mons in southern Belgium (Glibert \& Van de Poel 1973). It is thus only slightly younger than the specimens from Oman. Geloina lunulata (Deshayes, 1858) from the Thanetian (Palaeocene) of Châlons-surVesle in northern France again is not much younger
(Pacaud 1994). Interestingly, both Palaeocene species are small (maximum length of $25 \mathrm{~mm}$ ), like the new species from Al-Khodh. Several other species of Geloina were reported from the Eocene and Oligocene of France and England (Glibert \& Van de Poel 1966). No younger records are available from Europe. Extant Geloina has an Oriental to Australasian distribution, occurring from Pakistan eastward to New Caledonia (Huber 2015). The genus has been present in Asia at least since the Eocene (Japan, Malaysia; Nagao \& Otatume 1943, Suzuki 1949, Kanno 1978, Matsubara et al. 2010), and also has a scattered Neogene fossil record (Oostingh 1935; Taguchi 1981, 2002; Matsubara et al. 2004).

Summarising this information, the occurrence of $\mathrm{Ge}$ loina in the Campanian or Maastrichtian of Oman indicates 
either an early faunal link between Arabia and Eurasia, or suggests an African origin for the genus. For a brackishwater taxon, propagation of the larvae along the coastline or across narrow seaways, probably during phases of high freshwater run-off and associated layering of sea and river water, should be relatively straightforward. Accordingly, both an African origin and a Eurasian invasion of Geloina seem plausible. However, given that Africa has no fossil or extant record of Geloina, a Eurasian origin of the genus is considered to be more likely. Accordingly, Geloina amithoscutana, while being the oldest representative of the genus currently known, supposedly had earlier congeners in Asia and possibly Europe.

Of the brackish-water gastropod taxa, the palaeogeographical links of Subtemenia morgani are most revealing. This species was originally described from western Iran by Douvillé (1904) and has been reported earlier from Oman, some $200 \mathrm{~km}$ to the northwest of our study area (Smith et al. 1995). It seems that $S$. morgani was common during the Maastrichtian in the north and south of the Tethys. Although it is advisable to treat biostratigraphic insight provided by gastropods with caution, these occurrences seem to underpin a Maastrichtian age for the sampled strata of the Al Khodh Formation. The second species, Stephaniphera coronata is the only species in the new genus Stephaniphera. The Hemisinidae in general have a rather wide tropical to subtropical distribution range. Likewise, Ringiculidae had a wide spatial and temporal range in the Cretaceous. As a result, the latter two taxa offer little insight into the biogeographic relationships of the fauna from Al Khodh.

Of the marginal marine fossil community from the Jafnayn Limestone Formation only two taxa are determined at species level: Torquesia contumescens was first described from the Campanian to Maastrichtian Ariyalur Group in southeast India (Stoliczka 1868). In addition, $T$. contumescens was recorded from Gabon (West Africa) by Dartevelle \& Brebion (1956). Considering the extensive and rather complicated dispersal route around the northern half of the African continent, this record might represent a different species. The type locality of Amaurellina nuttalli is situated relatively close to northern Oman, in Balochistan Province of southwestern Pakistan (Douvillé 1929). The type stratum, the 'Cardita beaumonti Beds', was originally considered to be Danian in age (Cossmann \& Pissarro 1927, Douvillé 1929), but, according to Crame (2013, appendix s1), it might actually be slightly older, probably Maastrichtian. The Jafnayn Limestone Formation is currently dated as late Paleocene to basal Eocene, based on echinoids (Nolan et al. 1990). The records of Torquesia contumescens and Amaurellina nuttalli, in contrast, would argue for an earlier, possibly even Maastrichtian onset of this unit. We consider the biostratigraphic evidence from both the echinoids and the gastropods as rather weak, and thus regard the age of the mollusc assemblage as unsettled (Maastrichtian/?Paleocene).

\section{Palaeoecology}

The molluscs described herein were part of four different mollusc communities, which thrived at different salinity levels. In succession, these communities testify to an overall transgressive trend in northern Oman during the Campanian to Maastrichtian, and thus corroborate previous results from sedimentology (Nolan et al. 1990).

(1) The unionid community, composed of the three indeterminate species of unionids, is indicative of freshwater. Given that the shells are disarticulated and strongly eroded the unionids probably lived in a fluvial environment. The unionid community occurs only at one locality (MP3).

(2) The Geloina association is dominated by Geloina amithoscutana. At three localities, Subtemenia morgani also occurs. Oysters are associated with these two species and a ringiculid at locality MP 7, and further occur at locality MP10. Additionally, the small planispiral ampullariid gastropod Lanistes sp. of Pickford (2017) is present at locality MP7. Extant Geloina occur in estuaries and mangroves, commonly at or above the tide line, at the landwater interface, exposed to significantly lowered levels of salinity (11 to 22 practical salinity units; Morton 1976). Presumably, the Geloina association thus indicates lower mesohaline conditions. As at Al-Khodh, the preferred substrate of modern Geloina is coarse sand (Morton 1976). The Geloina association is the most common association in the samples from Al-Khodh, occurring at eight localities (MP1, 2, 4-7, 9 and 10). It should be noted that modern Lanistes species are restricted to freshwater. The presence of these gastropods at locality MP7 might

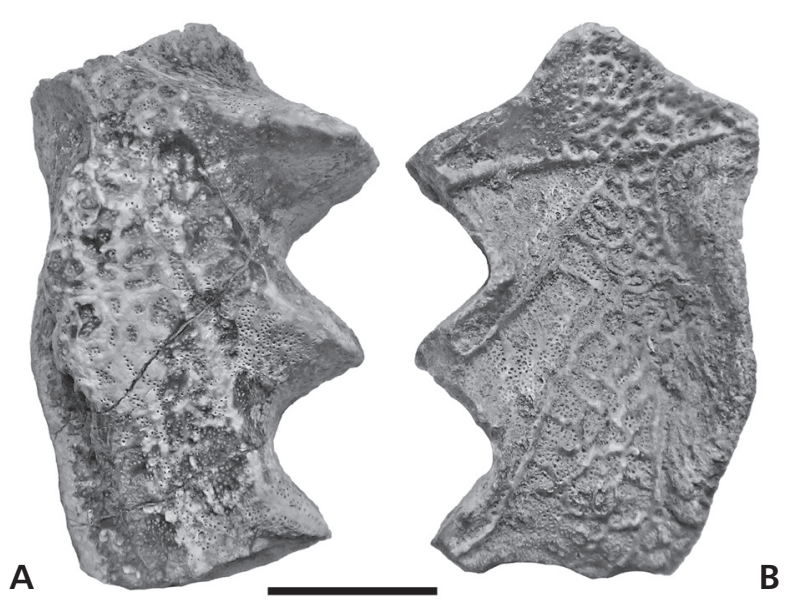

Figure 10. Dental plate of lungfish Ceratodus sp., locality MP 13; A - external view; B - internal view. Scale bar $=10 \mathrm{~mm}$. 
thus indicate that they have been washed in from nearby freshwater habitats.

(3) The Muscatella association occurs at four localities (MP 8, MP 13, MP 14 and AK 51). It is dominated by Muscatella biszczukae, which is associated with Subtemenia morgani at two localities. Additionally, Stephaniphera coronata occurs at two localities with Muscatella. Oysters and the small planispiral Lanistes of Pickford (2017) are present at locality AK51 (see comments on this species above). At locality MP13, a tooth plate of a lung fish (Ceratodus) was found together with the molluscs (Fig. 10). Modern lungfish commonly prey on shellfish and crustaceans (e.g. Kemp 1987, Witte $\&$ de Winter 1995), and the fossil species may thus have also fed on the molluscs described herein. An upper mesohaline or polyhaline regime seems likely for this association. It should be noted that Subtemenia morgani has also been recorded from marine strata in Oman (Smith et al. 1995), suggesting that it was an opportunistic, highly adaptable species.

(4) A marginal marine mollusc community is recorded from a single locality, 'Fanja Back', and composed of five taxa: the gastropods Torquesia contumescens, Amaurellina nuttalli and Pyrazus sp., and a questionable tellinid as well as other heterodont bivalves. Together, these taxa indicate shallow marine, nearshore conditions. Recent Batillariidae, including Pyrazus, occupy sandy and rocky habitats within the lower tidal regime in warm-temperate latitudes (Ozawa et al. 2009).

\section{Conclusions}

During the latest Cretaceous (late Campanian to Maastrichtian) the deltaic complex of the Al-Khodh Formation (northern Oman) harboured a mollusc fauna that is remarkable in several aspects. A freshwater community of three species of Unionidae represents the earliest record of large freshwater bivalves from the Arabian Peninsula from an island bounding a vast epicontinental sea to the southwest and the Tethys Ocean to the northeast during the time of deposition. Two brackish-water associations are indicative of different salinity regimes. The Geloina association, inhabiting mesohaline high-energy coarsegrained sandy environment, is dominated by the cyrenid Geloina amithoscutana sp. nov., the earliest representative of the genus Geloina, and the first one recorded outside Eurasia. Oysters and three gastropods, Subtemenia morga$n i$, Lanistes (?allochthonous) and an undetermined ringiculid, share this habitat. A second cyrenid, Muscatella biszczukae gen. nov. sp. nov., dominates the upper mesohaline to polyhaline Muscatella association. Subtemenia morgani, Stephaniphera coronata gen. nov. sp. nov. and Lanistes (?allochthonous) form its gastropod component. The molluscs were probably preyed upon by ceratodontid fish. These molluscs document the transition from freshwater to marine habitats within a single, relatively short-lived, deltaic succession, opening a window in the fossil record that is not often preserved. Shallow marine environment is exemplified by a Maastrichtian/?Paleocene mollusc community from the overlying Jafnayn Limestone Formation, where the gastropods Torquesia contumescens, Amaurellina nuttalii and Pyrazus are accompanied by heterodont bivalves.

Moreover, Subtemenia morgani, Torquesia contumescens and Amaurellina nuttalii document palaeobiogeographic relationships to Iran and Pakistan at the time on the northern coast of the Tethys, and to the still relatively distant shores of southeastern India. Geloina, which was thought to be of entirely Eurasian distribution, provides additional evidence for faunal relationships to the opposite side of the Tethys. As a whole, the mollusc fauna from AlKhodh is an important piece in the still rather incomplete puzzle of faunal development in the Middle East.

\section{Acknowledgements}

Our sincere thanks go to Mohammed Al-Kindi, Geological Society of Oman, Muscat, who organised and funded the expedition in September, 2014, in collaboration with the Oman Natural History Museum, Muscat, which curates the fossils collected and with the Botanical Garden, Al-Khodh, where the outcrops occur. Delphine Desmares, University of Paris VI and Romain Thomas, Muséum National d'Histoire Naturelle, Paris joined MP for this survey and helped collecting the material. Thomas A. Neubauer, Justus-Liebig-University Giessen, Germany, kindly provided literature, expert opinion on gastropod taxonomy, and a detailed review, which, together with a second careful review by Andrzej Kaim, Polish Academy of Sciences, Warsaw, helped to improve the manuscript.

\section{References}

Adams, H. \& Adams, A. 1853-1858. The genera of Recent Mollusca arranged according to their organisation. Volume 1, i-xi, 1-484, Volume 2, 1-660, Volume 3, 138 pls. Van Voorst, London. [Published in parts: Vol. 1: i-xl (1858), 1-256 (1853), 257-484 (1854); Vol. 2: 1-92 (1854), 93-284 (1855), 285-412 (1856), 413-540 (1857), 541-661 (1858); Vol. 3: pl. 1-32 (1853), 33-96 (1855), 97-112 (1856), 113-128 (1857), 129-138 (1858)]

Araujo, R., Buckley, D., Nagel, K.-O., García-Jiménez, R. \& Machordom, A. 2018. Species boundaries, geographic distribution and evolutionary history of the Western Palearctic freshwater mussels Unio (Bivalvia: Unionidae). Zoological Journal of the Linnean Society 182, 275-299.

DOI 10.1093/zoolinnean/zlx039 
BARNES, R.S.K. 1999. The conservation of brackish-water systems: priorities for the 21 st century. Aquatic Conservation: Marine and Freshwater Ecosystems 9, 523-527.

DOI 10.1002/(SICI)1099-0755(199911/12)9:6<523::AIDAQC368>3.0.CO;2-A

BAYAN, F. 1873. Etudes faites dans la collection de l'Ecole des Mines sur des fossiles nouveaux ou mal connus, Deuxième fascicule, 2. Notes sur quelques fossiles tertiaries. 91-136 pp. F. Savy, Paris.

Beu, A.G., Alloway, B.V., Pillans, B.J., Naish, T.R. \& WestGATE, J.A. 2004. Marine Mollusca of oxygen isotope stages of the last 2 million years in New Zealand. Part 1: Revised generic positions and recognition of warm-water and coolwater migrants. Journal of the Royal Society of New Zealand 34, 111-265. DOI 10.1080/03014223.2004.9517766

Bieler, R., Mikkelsen, P.M., Collins, T.M., Glover, E.A., González, V.L., Graf, D.L., Harper, E.M., Healy, J., Kawauchi, G.Y., Sharma, P.P., Staubach, S., Strong, E.E., Taylor, J.D., TËmkin, I., Zardus, J.D., Clark, S., Guzmán, A., McIntyre, E., Sharp, P. \& Giribet, G. 2014. Investigating the Bivalve Tree of Life - an exemplar-based approach combining molecular and novel morphological characters. Invertebrate Systematics 28, 32-115. DOI 10.1071/IS13010

Blainville, H.M.D. DE 1814. Mémoire sur la classification méthodique des animaux mollusques, et établissement d'une nouvelle considération pour y parvenir. Bulletin des Sciences par la Société Philomatique de Paris, Zoologie 1814, 175-180.

Blanckenhorn, M. 1927. Die fossilen Gastropoden und Scaphopoden der Kreide von Syrien-Palästina. Palaeontographica 69, 111-186.

Bogan, A.E. 2008. Global diversity of freshwater mussels (Mollusca, Bivalvia) in freshwater. Hydrobiologia 595, 139-147. DOI 10.1007/s10750-007-9011-7

Bolotov, I.N., Pfeiffer, J.M., Konopleva, E.S., Vikhrev, I.V., Kondakov, A.V., Aksenova, O.V., Gofarov, M.Yu., Tumpeesuwan, S. \& Win, T. 2018. Ancient river inference explains exceptional Oriental freshwater mussel radiations. Scientific Reports 7, 2135.

DOI 10.1038/s41598-017-02312-z

Bolotov, I.N., Vikhrev, I.V., Kondakov, A.V., Konopleva, E.S., Gofarov, M.Yu., Aksenova, O.V. \& Tumpeesuwan, S. 2017. New taxa of freshwater mussels (Unionidae) from a speciesrich but overlooked evolutionary hotspot in Southeast Asia. Scientific Reports 7, 11573.

DOI 10.1038/s41598-017-11957-9

Bosworth, W. 2015. Geological evolution of the Red Sea: historical background, review, and synthesis, 45-78. In Rasul, N.M.A. \& Stewart, I.C.F. (eds) The Red Sea. Springer, Berlin \& Heidelberg. DOI 10.1007/978-3-662-45201-1_3

Bouchet, P. \& Rocroi, J.-P. 2005. Classification and nomenclator of gastropod Families. Malacologia 47, 1-397.

Bouchet, P., Rocroi, J.-P., Hausdorf, B., Kaim, A., Kano, Y., Nützel, A., Parkhaev, P., Schrödl, M. \& Strong, E.E. 2017. Revised classification, nomenclator and typification of gastropod and monoplacophoran families. Malacologia 61, 1-526. DOI 10.4002/040.061.0201
Bourguignat, J.-R. 1852. Testacea novissima quac Cl. de Saulcy in itinere per Orientem annis 1850 et 1851, collegit. 31 pp. J.-B. Baillière, Lutetiae.

BRUGUIÈRE, J.G. 1792. Encyclopédie méthodique ou par ordre de matières. Histoire naturelle des vers. Tome premier. 757 pp. Panckoucke, Paris. DOI 10.5962/bhl.title.49857

CAsey, R. 1955. The pelecypod family Corbiculidae in the Mesozoic of Europe and the Near East. Palaeontology 45, 366-372.

Cossmann, M. 1908. Pélécypodes du Montien de Belgique. Mémoires du Musée Royal d'Histoire Naturelle de Belgique 5, 1-76. DOI 10.5962/bhl.title.13768

Cossmann, M. 1909. Essais de Paléoconchologie comparée, Huitième livraison. 248 pp. Privately published, Paris.

Cossmann, M. 1921. Essais de Paléoconchologie comparée. Douzième livraison. 348 pp. Privately published, Paris.

Cossmann, M. \& Peyrot, A. 1919. Conchologie néogénique de l'Aquitaine. Tome 3, Gastropodes, Scaphopodes et Amphineures, livraison 2, 385-695, Société Linnéenne de Bordeaux \& Actes de la Société Linnéenne de Bordeaux 70 (3), 181-356. [simultaneously published]

Cossmann, M. \& Pissarro, G. 1927. The Mollusca of the Ranikot Series. Part II. Brachiopoda and Lamellibranchiata (together with some species from the Cardita beaumonti beds). Memoirs of the Geological Survey of India, Palaeontologia Indica, N.S. 10(2), 1-31.

Cox, L.R. 1960. Thoughts on the classification of the Gastropoda. Proceedings of the Malacological Society of London 33, 239-261.

Crame, J.A. 2013. Early Cenozoic differentiation of polar marine faunas. PLoS ONE 8(1), art. e54139.

DOI 10.1371/journal.pone.0054139

Cuttelod, A., Seddon, M. \& Neubert, E. 2011. European Red List of non-marine molluscs. 97 pp. Publications Office of the European Union, Luxembourg.

Cuvier, G. 1795. Second mémoire sur l'organisation et les rapports des animaux à sang blanc, dans lequel on traite de la structure des mollusques et de leur division en ordre, lu à la société d'Histoire Naturelle de Paris, le 11 Prairial an troisième [30 May 1795]. Magazin Encyclopédique, ou Journal des Sciences, des Lettres et des Arts, 1795 [1. année] 2, 433-449.

DALL, W.H. 1903. Contributions to the Tertiary fauna of Florida with especial reference to the silex-beds of Tampa and the Pliocene beds of the Caloosahatchie River, including in many cases a complete revision of the generic groups treated and of their American Tertiary species, Part VI, concluding the work. Transactions of the Wagner Free Institute of Science of Philadelphia 3(6), 1219-1654. DOI 10.5962/bhl.title.29760

Dartevelle, E. \& Brebion, P. 1956. Mollusques fossils du Crétacé de la Côte occidentale d'Afrique du Cameroun à l'Angola. I. Gastéropodes. Annales du Musée Royal du Congo Belge, Série in $8^{\circ}$, Sciences géologiques 15, 1-128.

Delpey, G. 1937. Révision du genre Microschiza Gemmellaro.

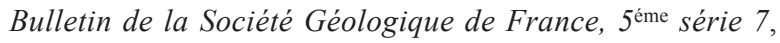
419-424. 
Deshayes, G.-P. 1839-1857. Traité élémentaire de Conchyliologie, avec les applications de cette science à la géologie, Tome premier, Première Partie, Introduction, i-xii [1853], 1-368 [1839], Seconde Partie, Conchifères dimyaires, 1-128 [1839], 129-824 [1850], Tome secondaire, 1-194 [1857]. 195-384 [1858], Explication des Planches, 1-24 [1839], 25-48 [1850], 49-80 [1853], Appendice a l'explication des planches, i-iv [1850], v-xi [1857], Masson, Paris.

Deshayes, G.-P. 1858. Description des animaux sans vertèbres découverts dans le Bassin de Paris pour servir de supplément a la description des coquilles fossiles des environs de Paris, comprenant une revue générale de toutes les espèces actuellement connues, tome premier, texte, mollusques acéphalés dimyaires, accompagné d'un atlas de 89 planches, fascicule 3. 393-704 pp. J.-B. Baillière et Fils, Paris.

Do, V.T., Tuan, L.Q. \& Bogan, A.E. 2018. Freshwater mussels (Bivalvia: Unionida) of Vietnam: Diversity, distribution, and conservation status. Freshwater Mollusk Biology and Conservation 21, 1-18. DOI 10.31931/fmbc.v21i1.2018.1-18

DouviLlé, H. 1904. Paléontologie. Deuxième partie, Mollusques fossiles, 192-368. In Morgan, J. DE (ed.) Mission scientifique en Perse. Tome troisième, Études géologiques. Ernest Leroux, Paris.

Douvillé, H. 1929. Les couches à Cardita beaumonti. Memoirs of the Geological Survey of India, Palaeontologia Indica, N.S. 10(3), 27-72.

Dunhill, A.M., Benton, M.J., Twitchett, R.J. \& Newell, A.J. 2014. Testing the fossil record: Sampling proxies and scaling in the British Triassic-Jurassic. Palaeogeography, Palaeoclimatology, Palaeoecology 404, 1-11. DOI 10.1016/j.palaeo.2014.03.026

Fang, Z.-J., Chen, J.-H., Chen, C.-Z., Sha, J.-G., Lan, X. \& WEN, S.-X. 2009. Supraspecific taxa of the Bivalvia first named, described and published in China (1927-2007). The University of Kansas, Palaeontological Contributions, New Series 17, 1-157.

FERRARI, S.M. 2013. New Early Jurassic gastropods from westcentral Patagonia, Argentina. Acta Palaeontologica Polonica 58, 579-593.

FÉRussaC, A.E.J.P.J.F. D'AudebArd 1821-1822. Tableaux systématiques des animaux mollusques suivis d'un Prodrôme général pour tous les mollusques terrestres ou fluviatiles vivants ou fossiles. Première partie, Tableaux systématiques généraux, I-XLVII. Deuxième partie, Tableaux particuliers des mollusques terrestres et fluviatiles, Classe des Gastéropodes. 1, Tableau de la famille des limaces, 1-28. 2, Tableau de la famille des limaçons, 1-92. 3, Tableau de la famille des auricules, 93-114 pp. Arthus-Bertrand, Paris.

Fischer, J.-C. \& Weber, C. 1997. Révision critique de la Paléontologie française d'Alcide d'Orbigny, Volume 2, Gastropodes jurassiques. 300 pp. Masson, Paris.

Fischer, P. 1880-1887. Manuel de Conchyliologie et de Paléontologie Conchyliologique, ou Histoire naturelle des mollusques vivants et fossiles suivi d'un appendice sur les Brachiopodes par D. P. Oehlert. Savy, Paris, i-xxiv, 1-1369. [Published in parts: Fasc. 1, 1-112 (1880); Fasc. 2, 113-192 (1881); Fasc. 3, 193-304 (1881); Fasc. 4, 305-416 (1882);
Fasc. 5, 417-512 (1883); Fasc. 6, 513-608 (1883); Fasc. 7, 609-688 (1884); Fasc. 8, 689-784 (1885); Fasc. 9, 785-896 (1885); Fasc. 10, 897-1008 (1886); Fasc. 11, 1009-1369 (1887)].

Fischer, P. \& Crosse, H. 1870-1902. Études sur les mollusques terrestres et fluviatiles du Mexique et du Guatemala. Mission scientifique au Mexique et dans l'Amérique centrale, Recherches zoologiques, Septième partie. 702 pp., 731 pp. Imprimerie nationale, Paris. DOI 10.5962/bhl.title.46371

Fitzinger, L.J. 1833. Systematisches Verzeichniss der im Erzherzogthum Oesterreich vorkommenden Weichthiere, als Prodrom einer Fauna desselben. Beiträge zur Landeskunde Österreichs unter der Enns 3, 88-122.

DOI 10.5962/bhl.title.10037

FLEMING, J. 1822. The philosophy of zoology, a general view of the structure, functions and classification of animals, volume 2. 618 pp. Constable \& Co., Edinburgh.

DOI 10.5962/bhl.title.24597

Forster, C. 1844. The historical geography of Arabia; or, the patriarchal evidences of revealed religion: a memoir, with illustrative maps; and an appendix, containing translations, with an alphabet and glossary, of the Hamyaritic inscriptions recently discovered in Hadramaut. Volume 2. 509 pp. Duncan and Malcolm, London.

Gemmellaro, G.G. 1878-1882. Sui fossili del calcare cristallino delle Montagne del Casale e di Bellampo nella Provincia de Palermo. Giornale di Scienze Naturali ed Economiche 13, 116-212 [1878], 14, 157-212 [1879], 15, 98-137 [1882].

GILl, T. 1871. Arrangement of the families of mollusks. Smithsonian Miscellaneous Collections 227, i-xvi, 1-49.

Giribet, G. \& Distel, D.L. 2003. Bivalve phylogeny and molecular data, 45-90. In LydeArd, C. \& LindBerg, D.R. (eds) Molecular systematics and phylogeography of mollusks. Smithsonian Books, Washington, DC.

Glibert, M. \& Van de Poel, L. 1966. Les Bivalvia fossils du Cénozoique étranger des collections de l'Institut Royal des Sciences Naturelles de Belgique. IV. Heteroconchia. 2ème partie: Corbiculidae à Petricolidae (fin). Mémoires, Institut Royal des Sciences Naturelles de Belgique, Deuxième Série 82, 1-108.

Glibert, M. \& Van de Poel, L. 1973. Les Bivalvia du Danien et du Montien de la Belgique. Mémoires, Institut Royal des Sciences Naturelles de Belgique 175, 1-89.

GRAF, D.L. 2013. Patterns of freshwater bivalve global diversity and the state of phylogenetic studies on the Unionoida, Sphaeriidae, and Cyrenidae. American Malacological Bulletin 31, 135-153. DOI 10.4003/006.031.0106

Graf, D.L. \& Cummings, K.S. 2007. Review of the systematics and global diversity of freshwater mussel species (Bivalvia: Unionoida). Journal of Molluscan Studies 73, 291-314. DOI 10.1093/mollus/eym029

GraY, J.E. 1840. Shells of molluscous animals, 105-152. In Synopsis of the contents of the British Museum, forty-second edition. Woodfall \& Son, London.

Gray, J.E. 1842. Shells of molluscous animals, 48-92. In Synopsis of the contents of the British Museum, forty-fourth edition. Woodfall \& Son, London. 
Gray, J.E. 1847. List of the genera of Recent Mollusca, their synonyma and types. Proceedings of the Zoological Society of London 15, 129-219.

GraY, J.E. 1854. A revision of the arrangement of the families of bivalve shells. Annals and Magazine of Natural History, series 2, 14(79), 408-418. DOI 10.1080/03745485709496364

GRÜNDEL, J. 2012. Beschreibung einiger Gastropoden aus dem unteren und mittleren Jura des Großherzogtums Luxemburg. Revue de Paléobiologie 31, 115-125.

Gu, Z.-W. \& Yu, J.-S. 1999. Cretaceous bivalves of the region of Songhuajiang and Liaohe Rivers in northeastern China. Palaeontologia Sinica, series B 32, 1-115.

Harzhauser, M., Piller, W.E. \& Steininger, F.F. 2002. Circum-Mediterranean Oligo-Miocene biogeographic evolution - the gastropods' point of view. Palaeogeography, Palaeoclimatology, Palaeoecology 183, 103-133. DOI 10.1016/S0031-0182(01)00464-3

Healy, J.M. \& Wells, F.E. 1998. Superfamily Cerithioidea, 738-739. In Beesley, P.L., Ross, G.J.B. \& Wells, A. (eds) Mollusca, the Southern Synthesis. Fauna of Australia 5.

HeILPRIN, A. 1887. Explorations on the west coast of Florida and in the Okeechobee wilderness. With special reference to the geology and zoology of the Floridian Peninsula. Transactions of the Wagner Free Institute of Science and Philosophy 1, 1-134. DOI 10.5962/bhl.title.28296

Henderson, J.B. 1935. Fossil non-marine Mollusca of North America. Special Papers, Geological Society of America 3, 1-313. DOI 10.1130/SPE3-p1

Hoernes, R. 1884. Elemente der Palaeontologie. 594 pp. Veit \& Co, Leipzig.

Houbrick, R.S. 1984. The relict cerithiid prosobranch, Gourmya gourmyi (Crosse), 240-242. In Eldredge, N. \& StAnley, S.M. (eds) Living fossils. Springer, New York, Berlin, Heidelberg, Tokyo. DOI 10.1007/978-1-4613-8271-3_29

Huber, M. 2015. Compendium of Bivalves 2. 907 pp. Conchbooks, Hackenheim.

KanNo, S. 1978. Brackish molluscan fauna (Upper Eocene) from the Silantek Formation in west Sarawak, Malaysia. Geology and Palaeontology of Southeast Asia 10, 103-112.

Keen, M. \& CAsey, R. 1969. Superfamily Corbiculacea Gray, 1847, n664-n670. In Moore, R.C. (ed.) Treatise on Invertebrate Palaeontology, Part N, Mollusca 6, Bivalvia, Volume 2. The Geological Society of America \& The University of Kansas, Boulder \& Lawrence.

Kemp, A. 1987. The biology of the Australian lungfish, Neoceratodus forsteri (Krefft 1870). Journal of Morphology, 190, Supplement 1, 181-198. DOI 10.1002/jmor.1051900413

Kollmann, H.A. 1984. Megalonoda n. gen. (Melanopsidae, Gastropoda) aus der Oberkreide der Nördlichen Kalkalpen (Österreich). Annalen des Naturhistorischen Museums in Wien A86, 55-62.

Kollmann, H.A. 2005. Révision critique de la Paléontologie française d'Alcide d'Orbigny, Volume III, Gastropodes crétacés. 238 pp. Backhuys, Leiden.

KüHN, O. 1929. Beiträge zur Palaeontologie und Stratigraphie von Oman (Ost-Arabien). Annalen des Naturhistorischen Museums in Wien 43, 13-33.
Lamarck, J.B.P.A. De Monet de 1804. Sur les fossiles des environs de Paris. Annales du Muséum National d'Histoire Naturelle, Paris 5, 28-36.

Lamarck, J.B.P.A. De Monet de 1806. Suite des mémoires sur les fossiles des environs de Paris. Annales du Muséum d'Histoire Naturelle, Paris 7, 419-430.

LeEs, G.M. 1928. The geology and tectonics of Oman and of parts of south-eastern Arabia. Quarterly Journal of the Geological Society 84, 585-670.

DOI 10.1144/GSL.JGS.1928.084.01-04.24

Linnaeus, C. 1758. Systema naturae per regna tria naturae, secundum classes, ordines, genera, species, cum characteribus, differentiis, synonymis, locis. Editio decima, reformata. 824 pp. Laurentius Salvius, Holmiae. DOI 10.5962/bhl.title.542

Lopes-Lima, M., Burlakova, L., Karatayev, A.Y., Mehler, K., Seddon, M. \& Sousa, R. 2018. Conservation of freshwater bivalves at the global scale: diversity, threats and research needs. Hydrobiologia 810, 1-14.

DOI 10.1007/s10750-017-3486-7

Lopes-Lima, M., Sousa, R., Geist, J., Aldridge, D.C., Araujo, R., Bergengren, J., Bespalaya, Y., Bódis, E., Burlakova, L., Van Damme, D., Douda, K., Froufe, E., Georgiev, D., Gumpinger, C., Karatayev, A., Kebapçi, Ü., Killeen, I., Lajtner, J., Larsen, B.M., Lauceri, R., Legakis, A., Lois, S., Lundberg, S., Moorkens, E., Motte, G., Nagel, K.-O., Ondins, P., Outeiro, A., Paunovic, M., Prié, V., Proschwitz, T. von, Riccardi, N., Rudzīte, M., Rudzītis, M., Scheder, C., Şereflişan, H., Simić, V., Sokolova, S., Stoeckl, K., Taskinen, J., Teixiera, A., Thielen F., Trichkova, T., Varandas, S., Vicentini, H., Zajac, K., Zajac, T. \& Zogaris, S. 2016. Conservation status of freshwater mussels in Europe: state of the art and future challenges. Biological Reviews 92, 572-607. DOI 10.1111/brv.12244

Lovén, S.L. 1847. Malacozoologi. Konigliga VetenskapsAkademiens Förhandlinger 1847, 175-199.

Marwick, J. 1929. Tertiary molluscan fauna of Chatton, Southland. Transactions and Proceedings of the New Zealand Institute 59, 903-934.

Matsubara, T., Komori, K. \& Oishi, M. 2004. Discovery of Geloina (Bivalvia: Corbiculidae) from the Miocene Kadonosawa Formation in the Ninohe area, Iwate Prefecture, northeastern Japan, and its paleobiogeographic significance. Journal of the Geological Society of Japan 110, 765-770. DOI 10.5575/geosoc. 110.765

Matsubara, T., Kurita, H. \& Matsuo, H. 2010. Eocene Mollusca from the Tainohata Formation in Kôbe City, southwest Japan. Paleontological Research 14, 119-144.

DOI 10.2517/1342-8144-14.2.119

MCCluRe, H.A. 1984. Quaternary palaeoenvironments of the Rub 'al Khali. 245 pp. Ph.D. thesis, Department of Geography, University College London.

MeEK, F.B. 1871. Preliminary paleontological report, 287-318. In Hyden, F.V. (ed.) Preliminary report of the United States Geological Survey of Wyoming and portions of contiguous territories, (being a second annual report of progress). Government Printing Office, Washington. 
Megerle von Mühlfeld, J.C. 1811. Entwurf eines neuen Systems der Schaltiergehäuse. Magazin für die neuesten Entdeckungen in der gesammten Naturkunde von der Gesellschaft Naturforschender Freunde zu Berlin 5(1), 38-72.

MolluscaBase 2018. Accessed at http://www.molluscabase.org on 2018-07-21.

MOnTfort, P.D. DE 1810. Conchyliologie systématique et classification méthodique des coquilles; offrent les figures, leur arrangement générique, leurs descriptions caractéristiques, leur noms; ainsi que leur synonymie en plusieurs langues. Tome second. 676 pp. F. Schoell, Paris.

Morton, B. 1976. The biology and functional morphology of the Southeast Asian mangrove bivalve, Polymesoda (Geloina) erosa (Solander, 1786) (Bivalvia: Corbiculidae). Canadian Journal of Zoology 54, 482-500. DOI 10.1139/z76-055

MüLlER, O.F. 1774. Vermium terrestrium et fluviatilium, seu animalium Infusiorum, Helminthicorum, et Testaceorum, non marinorum, succincta historia. Volumen alterum: Testacea. 214pp. Heineck \& Faber, Havniae et Lipsiae.

DOI 10.5962/bhl.title.12733

Nagao, T. \& Otatume, L. 1943. The fossil corbiculids from the Paleogene Isikari series in the Ishikari coal-field, Hokkaido. Journal of the Faculty of Science, Hokkaido Imperial University, series 4, 7, 1-13.

Neubauer, T.A. 2016. A nomenclator of extant and fossil taxa of the Melanopsidae (Gastropoda, Cerithioidea). ZooKeys 602, 1-358. DOI /10.3897/zookeys.602.8136

Neubauer, T.A., Harzhauser, M., Mandic, O., Georgopoulou, E. \& Kroh, A. 2016. Paleobiogeography and historical biogeography of the non-marine caenogastropod family Melanopsidae. Palaeogeography, Palaeoclimatology, Palaeoecology 444, 124-143.

DOI 10.1016/j.palaeo.2015.12.017

Neubert, E. 1998. Annotated checklist of the terrestrial and freshwater molluscs of the Arabian Peninsula with descriptions of new species. Fauna of Arabia 17, 333-461.

Neumayr, M. 1884. Zur Morphologie des Bivalvenschlosses. Sitzungsberichte der Mathematisch-Naturwissenschaftichen Klasse der Kaiserlichen Akademie der Wissenschaften 88, 385-419.

Newell, N.D. 1965. Classification of the Bivalvia. American Museum Novitates 2206, 1-25.

Nolan, S.C., Skelton, P.W., Clissold, W.P. \& Smewing, J.D. 1990. Maastrichtian to early Tertiary stratigraphy and palaeogeography of the Central and Northern Oman Mountains, 495-519. In Robertson, A.H.F., Searle, M.P. \& Ries, A.C. (eds) The geology and tectonics of the Oman region. Geological Society London, Special Publication 49. DOI 10.1144/GSL.SP.1992.049.01.31

Oostingh, C.H. 1935. Die Mollusken des Pliozäns von Boemiajoe (Java). Dienst van den Mijnbouw in Nederlandsch-Indië, Wetenschappelijke Mededeelingen 26, 1-247.

OpINION 493, 1957. Designation under the plenary powers of a type species in harmony with established usage for the genus 'Torquesia' Douville, 1929 (Class Gastropoda). Opinions and declarations rendered by the International Commission on Zoological Nomenclature 17, 255-264.
Orbigny, A. D’ 1842-1843. Paléontologie française. Description zoologique et géologique de tous les animaux Mollusques et Rayonnés fossiles de France. Terrains crétacés. Tome 2, Gastéropodes. 1-80 [1842], 81-456 [1843]. Artus Bertrand, Paris.

Orbigny, A. D' 1851-1860. Paléontologie française. Description zoologique et géologique de tous les animaux Mollusques et Rayonnés fossiles de France, comprenant leur application à la reconnaissance des couches. Terrains jurassiques. Tome 2, Gastéropodes. 1-112 [1851], 113-232 [1852], 233-336 [1853], 337-384 [1852], 385-424 [1854], 425-480 [1855], 481-520 [1856], 521-536 [1857], 537-621 [1860]. Victor Masson, Paris.

Ozawa, T., Köhler, F., Reid, D.G. \& Glaubrecht, M. 2009. Tethyan relicts on continental coastlines of the northwestern Pacific Ocean and Australasia: molecular phylogeny and fossil record of batillariid gastropods (Caenogastropoda, Cerithioidea). Zoologica Scripta 38, 503-525. DOI 10.1111/j.1463-6409.2009.00390.x

Pacaud, J.-M. 1994. Polymesoda (Geloina) lunulata (Deshayes) (Mollusca: Bivalvia: Corbiculidae). Cossmanniana 3, 55-56.

Philby, H. Sт. John B. 1933. The Empty Quarter: Being a Description of the Great South Desert of Arabia Known as Rub'al Khali. 433 pp. Constable \& Co. Ltd., London.

Philippi, R.A. 1853. Handbuch der Conchyliologie und Malacozoologie. 547 pp. Anton, Halle.

DOI 10.5962/bhl.title.10373

Pickford, M. 2017. Late Cretaceous Lanistes (Mollusca, Gastropoda) from Al-Khodh, Oman. Al Hajar 23, 15-27.

Pictet, F.-J. \& CAmpiche, G. 1861-1864. Description des fossiles du terrain crétacé des environs de Sainte-Croix. Deuxième partie. Matériaux pour la Paléontologie Suisse. 752 pp. H. Georg, Genève.

Powell, A.W.B. \& Bartrum, J.A. 1929. The Tertiary (Waitematan) Molluscan Fauna of Oneroa, Waiheke Island. Transactions and Proceedings of the New Zealand Institute 60, 395-447.

Prime, T. 1867. Notes on species of the family Corbiculadæ, with figures. Annals of the Lyceum of Natural History of New York 8, 57-92, 213-237, 414-418. DOI 10.1111/j.1749-6632.1867.tb00329.x

RAFINESQUe, C.S. 1820. Monographie des coquilles bivalves fluviatiles de la rivière Ohio, contenant douze genres et soixante-huit espèces. Annales Générales des Sciences Physiques 5(13), 287-322.

Roman, F. \& Mazeran, P. 1920. Monographie paléontologique de la faune du Turonien du bassin d'Uchaux et de ses dépendances. Archives du Museum d'Histoire naturelle de Lyon 12(2), 1-138.

Sandberger, F. 1870-1875. Die Land- und SüsswasserConchylien der Vorwelt. Keidel, Wiesbaden, 1-1000 [1: 1-48, pl. 1-4 (1870); 2-3: 49-96, pl. 5-12 (1870); 4-5: 97-160, pl. 13-20 (1871); 6-8: 161-256, pl. 21-32 (1872); 9-10: 257352, pl. 33-36 (1873); 11: 353-616 (1875); 12: 617-1000 (1875)]. DOI 10.5962/bhl.title.112296

Scotese, C.R. 2013. Map Folio 17, Late Cretaceous, (Maastrichtian, $68 \mathrm{Ma}$ ), 1-31. In Scotese. C.R. (ed.) PALEOMAP 
PaleoAtlas for ArcGIS, Volume 2, Cretaceous Paleogeographic, Paleoclimatic and Plate Tectonic Reconstructions.

Smith, A.B., Morris, N.J., Gale, A.S. \& Kennedy, W.J. 1995. Late Cretaceous carbonate platform faunas of the United Arab Emirates-Oman border region. Bulletin of the Natural History Museum, London, Geology Series 51, 91-119.

Sowerby, J. 1812-1822. The mineral conchology of Great Britain; or coloured figures and descriptions of those remains of testaceous animals or shells, which have been preserved at various times and depths in the earth. Volume 1, 1-32, pls 1-9 [1812], 33-96, pls 10-44 [1813], 97-178, pls 45-78 [1814], 179-234, pls 79-102 [1815]; Volume 2, 1-28, pls 103-114 [1815]; 29-116, pls 115-150 [1816], 117-194, pls 151-186 [1817], 195-235, pls 187-203 [1818]; Volume 3 , 1-40, pls 204-221 [1818], 41-98, pls 222-253 [1819], 99-126, pls 254-271 [1820], 127-184, pls 272-306 [1821]; Volume 4, 1-16, pls 307-318 [1821], 17-114, pls 319-383 [1822]. Meredith, London.

Sowerby, J. DE C. 1823-1845. The mineral conchology of Great Britain; or coloured figures and descriptions of those remains of testaceous animals or shells, which have been preserved at various times and depths in the earth. Volume 4, 115-148, pls 384-407 [1823]; Volume 5, 1-64, pls 408-443 [1823], 65-138, pls 444-485 [1824], 139-168, pls 486-503 [1825]; Volume 6, 1-86, pls 504-545 [1826], 87-156, pls 546-580 [1827], 157-200, pls 581-597 [1828], 201-230, pls 598-609 [1829], index [1840]; Volume 7, 1-8, pls 610-618 [1840], 9-16, pls 619-623 [1841], 17-24, pls 624-628 [1843], 25-56, pls 629-643 [1844], 57-80, pls 644-648 [1845]. Meredith, London.

Stache, G. 1880. Die Liburnische Stufe. Verhandlungen der $k$. $k$. Geologischen Reichsanstalt 1880(12), 195-209.

Stache, G. 1889. Die Liburnische Stufe und deren GrenzHorizonte. 1. Abteilung, Geologische Übersicht und Beschreibung der Faunen- und Floren-Reste. Abhandlungen der Kaiserlich-königlichen geologischen Reichsanstalt 13, $1-170$.

StoliczKa, F. 1867-1868. Cretaceous fauna of southern India, Volume 2. The Gastropoda. Memoirs of the Geological Survey of India, Palaeontologia Indica, Series 5, 1-497.

StoliczKa, F. 1870-1871. Cretaceous fauna of southern India, Volume 3. The Pelecypoda, with a review of all known genera of this class, fossil and Recent. Memoirs of the Geological Survey of India, Palaeontologia Indica, Series 6, 1-537.
SuzuKi, K. 1949. Development of the fossil non-marine molluscan faunas in eastern Asia. Japanese Journal of Geology and Geography 21, 91-133.

SwaInson, W. 1840. A treatise on malacology or shells and shellfish. 419 pp. Longman, London.

Szabo, S., Brondizio, E., Renaud, F.G., Hetrick, S., Nicholls, R.J., Matthews, Z., Tessler, Z., Tejedor, A., Sebesvari, Z., Foufala-Georgiou, E., da Costa, S. \& Dearing, J.A. 2016. Population dynamics, delta vulnerability and environmental change: comparison of the Mekong, Ganges-Brahmaputra and Amazon delta regions. Sustainable Science 1, 539-554. DOI 10.1007/s11625-016-0372-6

TAguchi, E. 1981. Geloina/Telescopium bearing molluscan assemblages from the Katsuta Group, Okayama Prefecturewith special reference to brackish faunal zonation in the Miocene of Japan. Bulletin of the Mizunami Fossil Museum 8, 7-20.

TAGUChI, E. 2002. Stratigraphy, molluscan fauna and paleoenvironment of the Miocene Katsuta Group in Okayama Prefecture, Southwest Japan. Bulletin of the Mizunami Fossil Museum 29, 95-133.

THIELE, J. 1929-1935. Handbuch der systematischen Weichtierkunde. Volume 1, part 1, 1-376 [1929], part 2, 377-778 [1931]; Volume 2, part 3, 779-1022 [1934], part 4, i-iv, 1023-1154, i-vi for Volume 1 [1935]. Gustav Fischer, Jena.

Van Damme, D., Bogan, A.E. \& Dierick, M. 2015. A revision of the Mesozoic naiads (Unionoida) of Africa and the biogeographic implications. Earth-Science Reviews 147, 141-200. DOI 10.1016/j.earscirev.2015.04.011

Wenz, W. 1938-1944. Gastropoda, Teil 1, Allgemeiner Teil und Prosobranchia1-1639. In Schindewolf, O.H. (ed.) Handbuch der Paläozoologie 6. Borntraeger, Berlin.

Witte, F. \& de Winter, W. 1995. Appendix II. Biology of the major fish species of Lake Victoria, 301-320. In WitTe, F. \& VAN DENSEn, W.L.T. (eds) Fish stocks and fisheries of Lake Victoria. A handbook for field observations. Samara Publishing Limited, Dyfed.

Zieritz, A., Bogan, A.E., Klishro, O., Kondo, T., Kovitvadhi, U., Kovitvadhi, S., Lee, J.H., Lopes-Lima, M., Pfeiffer, J.M., Sousa, R., Tu, D.V., Vikhrev, I., \& Zanatta, D.T. 2018. Diversity, biogeography and conservation of freshwater mussels (Bivalvia: Unionida) in East and Southeast Asia. Hydrobiologia 810, 29-44.

DOI 10.1007/s10750-017-3104-8 